\begin{tabular}{c}
\hline Review of \\
ECONOMICS \\
and \\
INSTITUTIONS
\end{tabular}

Review of Economics and Institutions ISSN 2038-1379 DOI:10.5202/rei.v9i1.240

Vol. 9 - No. 1, Spring-Summer 2018 - Article 2

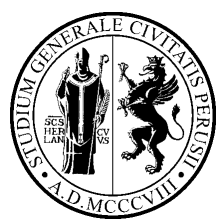

www.rei.unipg.it

\title{
Informal Economy and Extractive Institutions
}

\author{
Diego Coletto \\ Andrea Fracasso \\ Giuseppe Vittucci \\ Marzetti \\ University of Milano-Bicocca \\ University of Trento \\ University of Milano-Bicocca
}

\begin{abstract}
The paper aims at assessing the impact of the extractiveness of institutions on the size of the informal economy. After the identification of the variables suitable to proxy the distinct features of institutions, among which their extractiveness, the paper offers a battery of cross-section regressions over two large samples of developed and developing countries. The results suggest that the extractiveness of institutions is a significant determinant of the size of the informal economy and that greater informality is associated with a higher perceived distrust in formal institutions. The results are robust to the inclusion of standard controls, as well as proxies for culture, generalized trust and generalized morality.
\end{abstract}

JEL classification: O17, D02, P16, D73

Keywords: Informal economy, Extractive institutions, Institutional quality

\begin{abstract}
Acknowledgments: An earlier version of this paper was born thanks to the COD Project "The economic, social and political consequences of democratic reforms. A quantitative and qualitative comparative analysis" (ERC project). The authors acknowledge Giovanni Carbone, principal investigator of the COD project, who encouraged them to work on the relationships between democracy and informality. The authors are also indebted to an anonymous reviewer and to the participants in the workshop "Failing Institutions" at the University of Trento in November 2015 for insightful comments.
\end{abstract}

$\triangle$ Address: Department of Economics and Management \& School of International Studies, University of Trento, Italy (+39) 0461 282216, Email: andrea.fracasso@unitn.it

\section{Recommended Citation}

Coletto, D., Fracasso, A., Vittucci Marzetti, G., (2018). Informal Economy and Extractive Institutions. Review of Economics and Institutions, 9(1), Article 2. doi: 10.5202/rei.v9i1.240

Retrieved from http://www.rei.unipg.it/rei/article/view/240

Copyright (C) 2018 University of Perugia Electronic Press. All rights reserved 


\section{Introduction}

In the economic literature, as well as in some sociological and anthropological studies, the discussion about formal and informal activities has often resembled that on dualistic socio-economic environments (e.g. Portes et al., 1989; Guha-Khasnobis et al., 2006; Jutting and De Laiglesia, 2009; Kanbur, 2015), where some formal activities coming under the purview of the State coexist next to some activities falling outside it ${ }^{1}$. This notwithstanding, informality is not only a feature characterizing the early stages of development process but informal economic activities exist also in advanced countries (see, for instance, the evidence in Tanzi, 1999; Giles, 1999; Schneider and Enste, 2000, 2013; Portes and Haller, 2005; Jutting and De Laiglesia, 2009; Schneider et al., 2010; Charmes, 2012; ILO, 2011; ILOWIEGO, 2013; Schneider and Williams, 2013; Williams et al., 2015).

Informal activities can be thought as the result of repeated interactions, occurring at any stage of development, between self-interested (even though not necessarily rational and optimizing) individuals and the State. There cannot be informality without: i) the presence of some formal institutions that, in the very first place, define the set of formal interactions (Lomnitz, 1988); ii) individuals who choose to conceal their economic activities. Far from being a platitude, this observation makes clear that the size and the features of informal economic activities in a country depend on the interaction between the features of the formal institutions in place and the individual's incentives.

Economists and sociologists have long investigated the relations between the size of the informal economy and several economic and social factors (see, for instance, Portes et al., 1989; Schneider and Enste, 2000, 2013; Maloney, 2004; Chen, 2006; Coletto, 2010; Andrews et al., 2011; Buehn and Schneider, 2012). Among the usual suspects, one can find income per capita and inequality (Chong and Gradstein, 2007; Bhattacharya, 2011), credit markets (Bose, 1998; Straub, 2005), urbanization dynamics (Yuki, 2007; Kar and Marjit, 2009), taxes, regulations, enforcement and other government policies (Friedman et al., 2000; Ihrig and Moe, 2004; Dabla-Norris et al., 2008; Andrews et al., 2011; Prado, 2011), human capital endowments (La Porta and Shleifer, 2014), social welfare (Williams, 2014). High levels of taxes and regulatory burdens, in particular, have been often considered among the main determinants of the choice to undertake informal activities: those who feel overburdened by State interventionism, the reasoning goes, have an incentive to choose the "exit option" over the "voice option" (see

1 This is a central tenet of some fundamental studies, such as Boeke (1942, 1953), Hirschman (1957), Geertz (1963), Harris and Todaro (1970). 
Hirschman, 1970; De Soto, 1989; Schneider and Enste, 2000; Kus, 2010; Prado, 2011).

In spite of the fact that the relationship between the size of the informal economy and the levels of taxation and regulation, along with the complexity of the procedures necessary to abide by them, has become the object of abundant research (e.g. Loayza and Rigolini, 2006; Jutting and De Laiglesia, 2009; Torgler and Schneider, 2009; Kus, 2010; Andrews et al., 2011; Teobaldelli and Schneider, 2013; Williams, 2014, 2017; Adriaenssens and Hendrickx, 2015), little attention has been devoted to the role played by other important features of institutions and, in particular, their "extractiveness" (versus "inclusiveness").

Although the term "extractiveness" was originally used mainly to identify European colonizers exploiting the native population in colonized countries, more recently it has been used to characterize institutional systems where resources are surreptitiously diverted from the majority of the population towards a minority. In particular, as conceptualized by Acemoglu et al. (2001, 2005) and Acemoglu and Robinson (2012), "extractiveness" refers to the features of institutions that affect citizens' and firms' protection against forms of public abuse: for instance, lack of law and order and insecure property rights negatively affect agents' ability to appropriate the fruits of their efforts and to participate in a level playing field, while they facilitate the creation of rents and expose the same agents to government expropriations for the benefits of minorities.

The reasons we expect institution extractiveness to be relevant in the size of informal economy can be summarized as follows. As shown by Piketty (1995), Aghion et al. (2011), Berggren et al. (2015), and Grosjean et al. (2013), the perceived (input and output) "legitimacy" of the institutions alters citizens' attitudes towards public authorities and civil servants. Hence, to the extent that extractiveness affects their perceived "legitimacy", it likely modifies the extent of informal activities agents decide to undertake ${ }^{2}$. Moreover, given the established impact that the quality of property rights (as defined by Acemoglu and Johnson, 2005) yields on economic outcomes, extractive institutions likely alter the individual incentives to "exit" through the weakening of property rights. Accordingly, this work is not focused much on the impact of general and open-ended constitutional features of the institutional framework (e.g., the presence and quality of a formal

2 Our use of the term "legitimacy" is rather comprehensive and refers not only to a valuebased evaluation of the appropriateness of public structures and procedures (inputlegitimacy), but also to a more consequentialist assessment of government trustworthiness (Berggren et al., 2015). 
democratic set-up), but rather on the effect of a specific trait of the institutional environment, namely their extractiveness.

The paper contributes to the literature along several dimensions. Whereas the importance of extractiveness in affecting economic development is an established finding in the strand of the literature focusing on economic development, the same has not been acknowledged in the economic literature on the determinants of the size of informal activities. In the sociological literature on informality, only few works address different versions of the hypothesis that institutional features affect the size of the informal economy (see, among others, Feige, 1997; Centeno and Portes, 2006; Kus, 2010; Williams et al., 2015), and none has explicitly focused on extractiveness.

Moreover, most sociological contributions indirectly referring to issues associated with extractiveness have produced either unconditional bivariate cross-country correlations or multiple regressions lacking adequate controls. Many studies have adopted vague and far-reaching indicators to capture institutional features: given that such indicators cover overlapping institutional concepts, such works do not allow to draw clear cut conclusions on the impact of extractiveness. In addition, a number of sociological studies have focused on the relations between informal economy and institutions at the micro-level through single case studies: these are not directly comparable and that prevents from drawing general insights. In any event, no contribution has explicitly discussed the role of the extractiveness of institutions.

To the best of our knowledge, only few works have addressed similar research questions while adopting multivariate empirical analyses ${ }^{3}$. Teobaldelli and Schneider (2013) investigate whether the presence and the integrity of direct democratic institutions (such as popular initiatives and referendum) increase the opportunities for the citizens to exercise their "voice option" and reduce the extent to which they resort to "exit". Their

3 Although not directly tackling the extractiveness of institutions, Adriaenssens and Hendrickx (2015) combine individual responses to a European Social Survey with country-level data and estimate the impact of direct regulation, tax burden, State strength, social relations, generalized trust and institutional trust on the individual decision to undertake informal activities. In their work, State strength is envisaged as the effective enforcement and access to public order contract enforcement and this is closed to what we shall define as the effectiveness and efficiency of the public sector. This is different from the degree of extractiveness of institutions. It should also be noted in passing that, Adriaenssens and Hendrickx (2015) use to proxy for State strength the rule-of-law indicator; as we shall explain, this latter reflects by construction the degree to which people abide by the law and cannot be considered as distinct from informality. 
work differs from ours in that it focuses on the role of direct democracy rather than that of the extractiveness of institutions and it covers a limited sample of (at most) 57 countries while we cover a larger sample of countries (118). Torgler and Schneider (2009) investigate the impact of various broad governance indicators on informality, but they focus primarily on the impact of tax morale and their analysis covers at most 50 countries. Kus (2010) covers up to 78 countries, but the specification includes a limited number of explanatory variables (among which very broad and far reaching indicators).

The paper is structured as follows. Section 2 presents the idea of extractive institutions and discusses the main theoretical and methodological issues. The data are presented in Section 3 and the empirical specification in Section 4. The results are illustrated and discussed in Section 5. Section 6 concludes.

\section{Methodological caveats}

The first preliminary methodological issue that is worth discussing is what impact of institutions on the informal economy we intend to assess. In fact, institutions can affect the size of the informal economy directly, for they concur to shape the agents' incentives, but they can also affect it indirectly through their influence on the development process. There exists convincing evidence in the sociological and economic literature that institutions have a remarkable and long-lasting impact on many socioeconomic variables. Hence, to grasp the total (direct plus indirect) impact of institutions on the size of the informal economy, one should not control for those socio-economic variables that might impact on informal activities, but are in turn influenced by the quality of institutions. To grasp the direct impact of institutions on the informal economy, instead, all the other socioeconomic determinants are to be controlled for in the estimations. The direct impact that institutions have on informality has mainly to do with the short and medium run, whereas the total impact depends on the very long process through which institutions affect the economic and social conditions and these latter, eventually, influence the extent of informal activities. As anticipated, we shall focus on the direct impact of institutions on the size of the informal economy.

The second issue to address regards the criteria to choose the explanatory variables among the very many candidates introduced in the literature among the possible determinants of informal economy and economic growth. First, we shall look at variables which allow to proxy for the distinct features of institutions we are mainly interested in: the extractiveness of institutions, as well as their efficiency and effectiveness. As we aim to cover 
a sample of countries larger than those investigated in the previous literature on informality, we shall concentrate on those indicators that are available for more than 90 countries. However, both for the sake of completeness and to show the robustness of our main findings, we shall also perform a battery of estimations using additional indicators available for smaller samples. This second step will also allow to distinguish some important potential determinants of informality, such as trust and culture (as recommended, for instance, by Alesina and Giuliano, 2015), for which we do not have data for all the countries in the larger sample.

Figure 1. Size of informal economy (\% of official GDP) vs. WGI (2005)
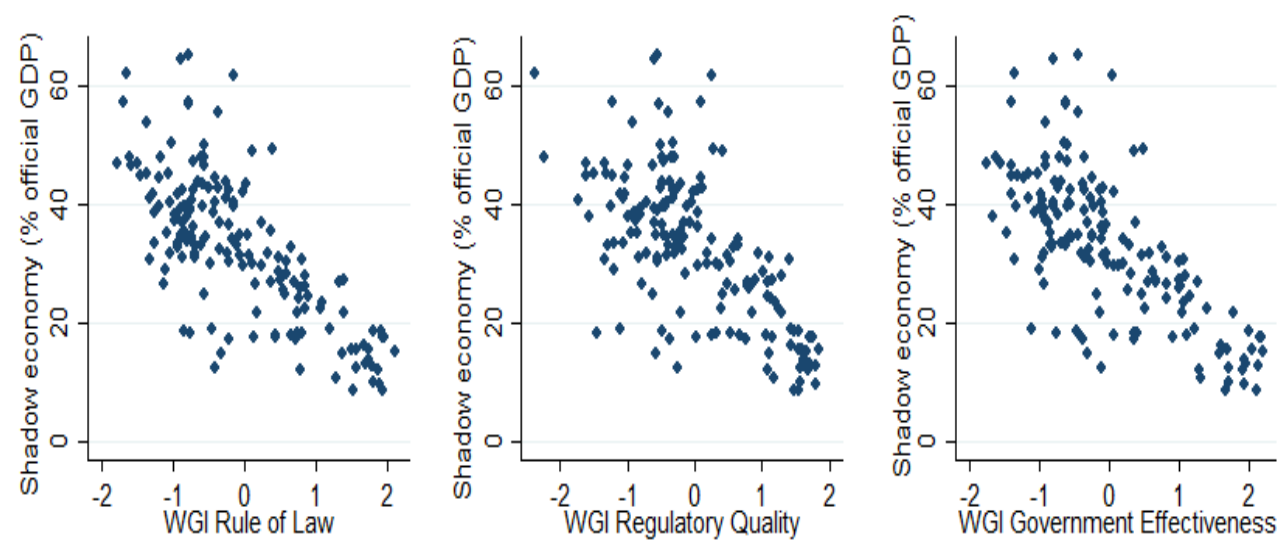

The first measures for the quality of institutions a researcher can think of are those in the World Governance Indicators (WGI) produced by Daniel Kaufmann and Art Kraay for the World Bank ${ }^{4}$. Indeed, the correlations between the size of informal economy, on the one hand, and the indicators for Government Effectiveness, Regulatory Quality, and Rule-of-Law, on the other hand, are very high (Figure 1). As shown by Torgler and Schneider (2009), such negative correlations are confirmed even when a number of plausible controls (such as GDP per capita, the share of the agricultural sector, unemployment rate, fiscal burden, government interventionism) are accounted for.

The problem with using these indicators is that, although to different extent, the WGI tend to summarize and "average" different concepts and aspects that a researcher interested in the precise features of institutions would like to disentangle. For instance, many WGI include (the perception about) the ability of a government to achieve results, the quality of the governmental objectives, the independence of the civil services from

4 The WGI draw on surveys of households and firms, commercial business information providers, non-governmental organizations, and public sector organizations. 
politicians, the obedience of the general public and of the civil servants to the rules, and the like: one can hardly distinguish bad (i.e., extractive) policies from good policies that are badly (i.e., inefficiently) implemented ${ }^{5}$.

Another issue with the WGI is that they often include sub-indicators that indirectly measure the informal economy: by construction, this artificially raises the correlation between the former and the latter. The WGI of the Rule-of-Law, for instance, covers the perceptions of the extent to which agents have confidence in and abide by the rules of society, that is in turn associated with the perceived dimension of the informal economy ${ }^{6}$.

To be clear, these observations do not amount to criticism of the WGI per se: as they are exactly meant to be synthetic measures of a country's institutional set-up, criticizing them for being far-reaching would be dull. Our claim, instead, is that these indicators do not help much to disentangle the impact of the two different aspects of institutions we are interested in: the extractiveness of institutions vs. their effectiveness/efficiency.

Accordingly, in what follows we shall focus on a number of measures that might be plausibly associated with either the degree of extractiveness of the institutions in place or with their effectiveness and efficiency. Following the literature on the determinants of economic growth, to proxy for institution extractiveness we include variables measuring the protection of property rights, the degree of judicial independence, the impartiality of courts, the extent of military interference in politics, and the constraints on the executive. These variables measure alternative channels through which private resources may be extracted and diverted by the ruling elites. Democratic institutions appear as those political contexts in which the accountability of the ruling parties and personal freedom are higher; therefore, we proxy extractiveness also by means of measures of the strength of political rights and a dummy variable looking at the absence/presence of (de facto) democratic institutions ${ }^{7}$.

5 This is one of the reasons why these indicators are very highly correlated, as noted by Easterly and Levine (2003).

6 Similar remarks hold true also for other broad indicators, such as the well known "Rule and Order" indicator by the PRS group. As the "Law" component refers to the strength and impartiality of the legal system and the "Order" one assesses popular observance of the law, the combined index does not only measure the quality of institutions, but also people's attitudes towards the rules, which are a manifestation rather than a determinant of the extent of informal activities.

7 Differently from Teobaldelli and Schneider (2013), we do not measure the quality of democracy with polychotomous classifications (such as the Polity IV index) covering both subjective and objective considerations. We focus instead on a dichotomous variable based on observable features regarding the mechanism for selecting and 
As to what concerns the effectiveness and efficiency of institutions, we introduce a number of variables that are associated with the complexity of the procedures to carry out in order to abide by the rules. A very long and complex procedure to solve a commercial controversy between private agents does not represent a tool to extract and reallocate resources, whereas it may signal inefficiencies in the functioning of institutions. Notably, these measures should not be confused with those capturing the burden of regulation (which is in turn a traditional determinant of the size of the informal economy we control for): even in very efficient administrations, regulations may be demanding because they regard very complicated aspects; on the contrary, even light regulations may lead to long lasting and time consuming procedures when institutions are inefficient.

While, from a theoretical perspective, State regulation can be justified as the attempt of the authorities to tackle market failures, regulations can also be used to divert resources towards restricted groups of citizens (see, for instance, Stigler, 1971) ${ }^{8}$. In this case, it could be argued that there is a direct relationship between the extractiveness of institutions and the efficiency of regulations and civil services. Accordingly, distinguishing these two aspects would not be entirely warranted. Although we acknowledge that there could be situations where inefficiency is associated with extractiveness, we maintain that it would be wrong to use the former as a proxy of the latter. On the one hand, even convoluted and time-consuming regulatory procedures might be well-intended and genuinely directed towards redressing market failures, and yet individuals may choose to circumvent them simply for the sake of saving time and costs. On the other hand, in countries where institutions are highly extractive, the levels of regulation might be in fact low for this facilitates discrimination and arbitrary decisions by the public officials. Bortolotti et al. (2013) introduce the case of States acting as reluctant regulators, because the weaker the political institutions, the more the politicians influence regulatory agencies so as to extract benefits for State-owned firms: this implies that the existence of a legally independent regulator (typically conceived as a good institutional feature) does not guarantee per se that the decisions are really

removing the executive. As pointed out by Cheibub et al. (2010), it is important to choose measures of democracy that are in line with the theoretical and empirical underpinnings of a testable hypothesis.

8 In principle, the identification of the demand of regulation by the citizens would allow to assess whether regulation is motivated by genuine concerns or not (see Aghion et al., 2010; Pinotti, 2012). In practice this is not a viable solution for a large cross-country analysis as the one we carry out here. 
independent. These examples effectively show why one needs to distinguish these factors in the empirical analysis.

A final caveat is in order. There is not a uniquely established definition of "informal economy" in the sociological and economic literature (see, for instance, Feige, 1990; Schneider and Enste, 2000, 2013; ILO, 2002; Hart, 2010; Andrews et al., 2011). Moreover, the estimates of the informal economy can be either based on indirect approaches (e.g., the currency demand approach, the electricity consumption method and the MIMIC model), grounded in discrepancies in national accounts, proxied by observed macroeconomic variables (such as self-employed, workers without contracts, employees without social security contributions, multiple-job holders, illegal immigrants and the like) or derived from micro-level surveys. To analyze the determinants of the size of the informal economy in the largest possible set of countries, this study borrows the recent estimates for the size of the shadow economy as percentage of the official GDP produced by Schneider et al. (2010) and computed by means of a MIMIC (Multiple Indicators Multiple Causes) model, a model that links a number of allegedly causal variables (tax burden, regulation density, tax morale, income) to a number of possible "indicators" of the size of the informal economy (increased monetary transactions, lower working hours and labor participation in the official economy, lower labor inputs in the official economy, decreased growth rates of official GDP). A factor-analysis is carried out to measure the informal economy as an unobserved variable over time. In particular, the MIMIC model consists of two parts: the first (the measurement model) links the unobserved variable (the informal economy) to the observed indicators; the second (the structural equations model) specifies the causal relationships for the unobserved variable. In so doing, it allows to consider both the multiple causes of the informal economy and its multiple effects over time (see Schneider and Enste, 2013, Chapter 3). 
Table 1. Variable description and summary statistics

\begin{tabular}{|c|c|c|c|c|c|c|c|}
\hline Variable & Description & Source & Obs & Mean & S.D. & Min & Max \\
\hline$\overline{\text { Informal economy }}$ & Shadow economy (\% of official GDP) & Schneider et al. (2010) & 118 & 33.0 & 13.2 & 8.5 & 65.1 \\
\hline GDP per capita & In expenditure-side real GDP PPPs per capita & PWT 8.1 & 118 & 8.53 & 1.33 & 5.88 & 11.42 \\
\hline Agriculture VA & In $\%$ agriculture value added on total value added & WDI & 118 & 2.14 & 1.27 & -2.85 & 4.20 \\
\hline Population above 65 & In \% population aged 65 and above on total population & WDI & 118 & 1.82 & 0.69 & 0.30 & 2.99 \\
\hline Pop largest city & In $\%$ population in the largest city on total urban population & WDI & 118 & 3.32 & 0.59 & 1.11 & 4.61 \\
\hline Fractionalization & Degree of ethnolinguistic fractionalization in 1985 & Roeder (2001) & 118 & 0.47 & 0.28 & 0 & 0.92 \\
\hline Protestants & $\%$ protestants on total population in 1980 & La Porta et al. (1999) & 118 & 11.6 & 20.6 & 0 & 97.8 \\
\hline Executive constraints & Constraints on executives ( 1 low -7 high) & Polity IV & 117 & 5.05 & 1.92 & 1 & 7.00 \\
\hline Military interference & Military interference in rule of law and politics ( 0 low -10 high) & Fraser Institute & 108 & 6.34 & 2.85 & 0 & 10 \\
\hline Reliability of police & Reliability of police (0 low -10 high) & Fraser Institute & 95 & 5.22 & 1.97 & 1.82 & 9.38 \\
\hline Democratic regime & Dummy for regimes with free elections and alternating parties & Cheibub et al. (2010) & 118 & 0.61 & 0.49 & 0 & 1 \\
\hline Age democracy & Years since the democratic transition & Cheibub et al. (2010) & 118 & 22.4 & 34.3 & 0 & 136 \\
\hline Political rights & political rights index (1 weak -7 strong) & Freedom House & 118 & 3.37 & 2.05 & 1 & 7 \\
\hline Legal rights & Strength of legal rights index ( 0 weak -10 strong) & WDI & 116 & 5.04 & 2.44 & 0 & 10 \\
\hline Impartiality of courts & Impartiality of courts ( 0 low -10 high) & Fraser institute & 108 & 4.69 & 1.95 & 0.93 & 9.2 \\
\hline Judicial independence & Judicial independence (0 low - 10 high) & Fraser institute & 94 & 4.71 & 2.33 & 0.31 & 9.18 \\
\hline Property rights protection & Protection of property rights ( 0 low -10 high) & Fraser institute & 94 & 5.98 & 1.92 & 1.44 & 9.61 \\
\hline Rents from natural resources & Rents from gas, oil and minerals (\% of GDP) & WDI & 118 & 9.89 & 17.9 & 0 & 79.75 \\
\hline Labor market regulations & Overall labor market regulations ( 0 high -10 low) & Fraser institute & 108 & 6.03 & 1.42 & 3 & 9.1 \\
\hline Hiring and firing regulations & Hiring and firing regulations ( 0 high -10 low) & Fraser institute & 94 & 4.84 & 1.57 & 1.69 & 8.16 \\
\hline Cost worker dismissal & Mandated cost of worker dismissal ( 0 high -10 low) & Fraser institute & 106 & 5.71 & 3.21 & 0 & 10 \\
\hline Hours regulations & Hours Regulations (0 high - 10 low) & Fraser institute & 108 & 7.18 & 1.90 & 3.3 & 10 \\
\hline Hiring regulations and min wage & Hiring regulations and minimum wage ( 0 high -10 low) & Fraser institute & 108 & 6.41 & 2.88 & 0 & 10 \\
\hline Bureaucracy costs & Bureaucracy costs ( 0 high -10 low) & Fraser institute & 94 & 4.61 & 1.74 & 0.46 & 9.94 \\
\hline Administrative burden & Administrative requirements ( 0 high -10 low) & Fraser institute & 94 & 3.43 & 1.12 & 1.39 & 6.79 \\
\hline Time to pay taxes & In days to prepare and pay taxes & WDI & 116 & 5.72 & 0.69 & 3.89 & 7.86 \\
\hline Time to resolve insolvency & In years to resolve insolvency & WDI & 112 & 0.96 & 0.55 & -0.92 & 2.30 \\
\hline Time to enforce a contract & In days to enforce a contract & WDI & 116 & 6.29 & 0.46 & 4.79 & 7.45 \\
\hline ICQ: tolerance and respect & Important child qualities: tolerance and respect & WVS (A032) & 47 & 0.71 & 0.13 & 0.36 & 0.94 \\
\hline
\end{tabular}


Table 1 (continued)

\begin{tabular}{|c|c|c|c|c|c|c|c|}
\hline Variable & Description & Source & Obs I & Mean & S.D. & Min & Max \\
\hline ICQ: unselfishness & Important child qualities: unselfishness & WVS (A041) & 47 & 0.35 & 0.13 & 0.07 & 0.61 \\
\hline ICQ: obedience & Important child qualities: obedience & WVS (A042) & 47 & 0.41 & 0.18 & 0.05 & 0.82 \\
\hline ICQ: feeling of responsibility & Important child qualities: feeling of responsibility & WVS (A032) & 47 & 0.73 & 0.14 & 0.39 & 0.92 \\
\hline ICQ: hard work & Important child qualities: hard work & WVS (A030) & 47 & 0.53 & 0.24 & 0.10 & 0.89 \\
\hline $\begin{array}{l}\text { Justifiable to avoid fare on public } \\
\text { transport }\end{array}$ & Justifiable: avoiding a fare on public transport (1-10) & WVS (F115) & 46 & 2.62 & 0.73 & 1.58 & 4.31 \\
\hline Justifiable to cheat on taxes & Justifiable: cheating on taxes (1-10) & WVS (F116) & 47 & 2.26 & 0.64 & 1 & 3.66 \\
\hline Justifiable to buy stolen goods & Justifiable: buying stolen goods (1-10) in 1995 & WVS (F139) & 44 & 1.82 & 0.42 & 1.11 & 3.19 \\
\hline Trust in family & Complete trust in family & WVS (D001) & 44 & 0.84 & 0.08 & 0.63 & 0.97 \\
\hline Generalized trust & Most people can be trusted & WVS (A165) & 46 & 0.28 & 0.17 & 0.05 & 0.74 \\
\hline No member of local community & See myself not as a member of local community & WVS (G020) & 41 & 1.69 & 0.20 & 1.26 & 2.19 \\
\hline No citizen of the country & See myself not as a citizen of the country & WVS (G021) & 41 & 1.49 & 0.18 & 1.14 & 1.84 \\
\hline Willingness to fight for country & Willingness to fight for the country & WVS (E012) & 46 & 0.71 & 0.17 & 0.25 & 0.97 \\
\hline Distrust in labor unions & Distrust: labor unions & WVS (E069-05) & 47 & 2.70 & 0.31 & 1.58 & 3.41 \\
\hline Distrust in police & Distrust: the police & WVS (E069-06) & 46 & 2.34 & 0.38 & 1.46 & 3.11 \\
\hline Distrust in Parliament & Distrust: Parliament & WVS (E069-07) & 46 & 2.68 & 0.43 & 1.23 & 3.38 \\
\hline Distrust in civil services & Distrust: the civil services & WVS (E069-08) & 47 & 2.59 & 0.33 & 1.63 & 3.38 \\
\hline Distrust in Government & Distrust: the Government & WVS (E069-11) & 45 & 2.55 & 0.41 & 1.22 & 3.26 \\
\hline Distrust in political parties & Distrust: the political parties & WVS (E069-12) & 46 & 2.92 & 0.36 & 1.44 & 3.42 \\
\hline Distrust in courts & Distrust: justice system/courts & WVS (E069-17) & 45 & 2.41 & 0.39 & 1.48 & 3.13 \\
\hline Dissatisfaction with democracy & Dissatisfaction with the way democracy develops (2000) & WVS (E110) & 37 & 2.58 & 0.43 & 1.41 & 3.24 \\
\hline
\end{tabular}
averages). 


\section{Data}

The largest sample is made up of 118 countries in $2005^{9}$. As discussed in the previous section, the dependent variable in our regressions is the size of the informal economy as a percentage of the official GDP computed by means of a MIMIC model, taken from Schneider et al. (2010).

Table 1 reports the descriptions, the sources and the summary statistics of all the variables used in the regressions.

Among the controls we include in every regression, there is the expenditure-side real GDP per capita in PPP (taken from the Penn World Table 8.1, 2005). This variable is meant to control for all the factors affecting the size of informal economy associated with the stage of economic development, as well as with the indirect effects of institutions (see Section 2).

We also control for the differences in the sectoral structure of the economy, by including among the regressors the share of agriculture value added, and also the demographic structure and the degree of urban concentration, by employing, respectively, the percentage of population aged 65 and above and the share of population in the largest city on total urban population. All these variables come from the World Bank World Development Indicators (WDI) for the year 2005.

Following the results in Lassen (2007) and Teobaldelli and Schneider (2013), we include an index of ethnolinguistic fractionalization present in 1985, and we also control for whether the most diffused religion is

9 The sample is made up of OECD countries (Australia, Austria, Belgium, Canada, Czech Republic, Denmark, Finland, France, Germany, Greece, Hungary, Ireland, Italy, Japan, Mexico, Netherlands, New Zealand, Norway, Poland, Portugal, Slovak Republic, South Korea, Spain, Sweden, Switzerland, Turkey, United Kingdom, United States) and nonOECD countries (Angola, Argentina, Armenia, Azerbaijan, Bangladesh, Belarus, Benin, Bolivia, Bosnia and Herzegovina, Brazil, Bulgaria, Burkina Faso, Burundi, Cambodia, Cameroon, Central African Republic, Chad, Chile, China, Colombia, Rep. Congo, Costa Rica, Cote d'Ivoire, Croatia, Dominican Republic, Ecuador, Egypt, El Salvador, Estonia, Ethiopia, Gabon, Georgia, Ghana, Guatemala, Guinea, Guinea-Bissau, Honduras, India, Indonesian, Iran, Jamaica, Jordan, Kazakhstan, Kenya, Kyrgyz Republic, Lao, Latvia, Lebanon, Liberia, Macedonia, Madagascar, Malawi, Malaysia, Mali, Mauritania, Moldova, Mongolia, Morocco, Mozambique, Namibia, Nepal, Niger, Nigeria, Oman, Pakistan, Panama, Paraguay, Philippines, Qatar, Rwanda, Saudi Arabia, Senegal, Sierra Leone, Singapore, South Africa, Sri Lanka, Tajikistan, Tanzania, Thailand, Togo, Tunisia, Uganda, Ukraine, Uruguay, Venezuela, Vietnam, Yemen, Zambia, Zimbabwe). 
Protestantism in order to pick some cultural and institutions-unrelated variables as done, for instance, in Teobaldelli and Schneider (2013) ${ }^{10}$.

Extractive institutions alter the allocation of public and private resources towards uses that do not maximize the population well-being, but that ensure that certain groups of individuals exploit the rest of the population. On the one hand, the general and open-ended constitutional features of the institutional framework should not capture the extractiveness of institutions; on the other hand, the actual functioning of the political and legal frameworks may reflect the ultimate goals of the ruling class and proxy their extractiveness. We test this hypothesis by employing a number of variables about the actual functioning of the institutional framework to see to what extent they exercise an influence on the size of the informal economy. In particular, we look at the presence of external constraints on the executive (Polity IV), the interventionism of the military in the political life (Fraser Institute), the reliability of the police (Fraser Institute), the presence or absence of democracy ${ }^{11}$, the age of the democratic regime (if present in 2005), the strength of political rights (Fraser Institute) and of legal rights (WDI), the impartiality of courts (Fraser Institute), judicial independence (Fraser Institute), and the protection of property rights (Fraser Institute).

To grasp how certain economic activities carried out under the direct control of the government may alter the incentives in the private sector, we employ among the proxies of extractiveness the share of GDP accruing to rents from the exploitation of natural resources (oil, gas and minerals) $(\mathrm{WDI})^{12}$.

According to previous theoretical studies on the determinants of the informal economy, the level of taxation and the burden of regulation are likely to play a leading role. According to the neoliberal approach following De Soto (1989), even in very efficient and probe administrations, regulations may be too burdensome and induce people to circumvent them by

10 Although not reported here, we estimated specifications including three dummies; besides the one taking value 1 if the majority of the population is Protestant, one taking one if Catholics are the majority, one for Muslim (La Porta et al., 1999). None of these variables turn out to be significant in any of the specifications and sub-samples.

11 We consider a dummy variable taking value 0 if one of the following conditions is present in 2005: little competition among multiple political parties, lack of alternating parties, non-elective procedures for the selection of the executive, absence of elective legislature. This variable is borrowed from Cheibub et al. (2010).

12 Besides adopting variables identified in previous works on extractive institutions, we try and include measures of both de jure and de facto institutions, so as to reflect both constitutional constraints and actual institutional outcomes (see Glaeser et al., 2004). 
"exiting". This view is contended by a number of scholars (see, for instance, Portes and Sassen-Koob, 1987; Williams, 2015), who maintain that such alleged relationship is not validated by empirical evidence. Hence, the hypothesis to test is that regulations might alter the incentives to switch into informality. In this respect, a set of variables we employ refer to labor markets: first, we use an overall indicator of labor market regulations elaborated by the Fraser Institute and then a series of sub-indicators (hiring regulations and minimum wage, hiring and firing regulations, hours regulations, mandated costs of worker dismissal) which participate in the construction of the overall indicator. Then, we employ a measure of the stringency of standards on product/service quality, energy and other regulations (outside environmental regulations) issued by the government; to this end, we employ the indicator elaborated by the Fraser Institute on the basis of the Global Competitiveness Report by the World Economic Forum.

Procedures may be burdensome either because they are stringent, or because the issue at stake is complex or, finally, because the regulatory framework is inefficient. In fact, even light regulations may lead to long lasting and time consuming procedures when institutions are inefficient. To pick up this effect we shall focus on specific measures that more directly proxy the efficiency of the institutions rather than the complexity of the issues to regulate: the number of days to prepare and pay taxes (in logs, from the WDI), the number of years to resolve insolvency (in logs, from the WDI), the number of days required to enforce a contract (in logs, from the WDI). We also look at the extent to which firms find that complying with the administrative requirements (permits, regulations, reporting) issued by the government is burdensome: we employ an index elaborate by the Fraser Institute on the basis of the Global Competitiveness Report by the World Economic Forum.

In order to test the role played by "cultural" factors and trust, we employ some variables built by elaborating the data in the 2005 wave of the World Values Survey. Limited data availability will force us to analyze a smaller set of countries (48). We shall run a battery of regressions to account for culture and trust, as well as for additional proxies of the quality of institutions that are available only for such a limited sample.

It is worth stressing again that, for the reasons explained in Section 2, we do not employ the aggregated indexes on the rule of law, government efficiency, and quality of regulation provided by the World Bank World Governance Indicators. Although highly significant variables in previous studies, these measures do not allow to disentangle the different phenomena we are interested in and often contain sub-indicators that overlap with specific forms of informal activities. 


\section{The empirical specification}

To address our research question, we estimate a specification including several plausible determinants of the size of the informal economy in view to exploiting the cross-country variation in the data for about 100 countries in the year 2005. This year allows to use recent estimates of informal economies while avoiding the variability brought about by the excesses due to market bonanza in 2006-2007 and the following global financial crisis. Moreover, analyzing previous years would have prevented from capturing the noticeable rise of a number of developing countries and would have reduced the size of the sample due to greater lack of reliable data for the explanatory variables and the controls in the early 2000 s.

As maintained in the previous sections, we include the explanatory factors proxing for the extractiveness of institutions, for the effectiveness and efficiency of the institutions, as well as the burden complexity of regulations. We also add to the specification those socio-economic controls that either were found significant in previous studies or may be intuitively associated with the indirect effects of institutions on informality (see Section 2). All the variables are computed for 2005 (or the closest year if 2005 is not available).

The most concise and general form we estimate looks like the following:

$$
I E_{i}=\alpha+\gamma X_{i}+\beta Q_{i}+\varepsilon_{i}
$$

where $I E_{i}$ is the size of informal in country $i, X_{i}$ is a vector containing several socio-economic controls, $Q_{i}$ is a vector of proxies for the quality of institutions we are interested in, $\varepsilon_{i}$ is the error term. As anticipated, $Q_{i}$ includes, in turn, proxies of the extractiveness of institutions in country $i$, proxies for their effectiveness and efficiency, and measures of the burden associated with the complexity of regulations.

\section{Results}

Tables 2 and 3 report the estimated coefficients in the different specifications. All the specifications share the same dependent variable and the same controls (in the upper part of the tables), i.e. the variables that the economic intuition and the literature suggest to be associated with the size of the informal economy, and each one differs from the others only in terms of the variable adopted to proxy for the extractiveness of institutions.

Table 2 includes the variables associated with the actual functioning of the democratic context (if present), the strength of political and legal rights, the interference of the military into the political life, the reliability of police, 
and the strength of the external constraints on the executive. Each of these variables, as argued, captures a feature of the institutional framework that may favor extractive policies and decisions from those who yield power.

All the parameters have the expected sign, but only the reliability of police and the age of the democratic regime have a statistically significant relationship with the size of the informal economy: the more the police is reliable and the more consolidated is the democratic regime, the lower the extent of informality.

Table 2. Informality and Institution Extractiveness (I)

\begin{tabular}{|c|c|c|c|c|c|c|c|}
\hline & (1) & (2) & (3) & (4) & (5) & (6) & (7) \\
\hline \multirow[t]{2}{*}{ GDP per capita } & -3.060 & -3.305 & -2.691 & -3.011 & -2.451 & -3.107 & $-3.796^{*}$ \\
\hline & $(1.927)$ & (2.157) & $(2.325)$ & $(1.935)$ & $(1.885)$ & (1.924) & $(1.974)$ \\
\hline \multirow[t]{2}{*}{ Agriculture VA } & $3.569 * *$ & $3.657 * *$ & 3.202 & $3.473 * *$ & $3.219^{*}$ & $3.313^{*}$ & $3.518 * *$ \\
\hline & (1.671) & $(1.763)$ & (1.935) & (1.681) & $(1.627)$ & $(1.673)$ & (1.705) \\
\hline \multirow[t]{2}{*}{ Population above 65} & $5.642 * *$ & $4.898^{*}$ & 3.986 & $3.832 *$ & $5.160 * *$ & $5.075^{* *}$ & $5.981 * *$ \\
\hline & $(2.433)$ & $(2.631)$ & $(3.001)$ & $(2.261)$ & $(2.108)$ & $(2.315)$ & $(2.416)$ \\
\hline \multirow[t]{2}{*}{ Population in largest city } & $5.102 * * *$ & $5.024 * * *$ & $4.835^{* * *}$ & $4.989 * * *$ & $4.171 * *$ & $4.983 * * *$ & $5.005 * * *$ \\
\hline & (1.614) & $(1.690)$ & $(1.726)$ & $(1.620)$ & $(1.597)$ & $(1.609)$ & $(1.628)$ \\
\hline \multirow[t]{2}{*}{ Fractionalization } & $9.864 * *$ & 8.394* & 5.665 & $8.847^{* *}$ & $9.336 * *$ & $9.475^{* *}$ & $9.487 * *$ \\
\hline & $(4.042)$ & (4.275) & $(4.630)$ & (3.981) & (3.858) & (3.987) & (4.044) \\
\hline \multirow[t]{2}{*}{ Protestants } & -0.049 & -0.042 & -0.0223 & -0.058 & -0.005 & -0.046 & -0.034 \\
\hline & $(0.046)$ & $(0.048)$ & $(0.050)$ & $(0.046)$ & $(0.048)$ & $(0.047)$ & $(0.048)$ \\
\hline \multirow[t]{2}{*}{ Executive constraints } & -0.789 & & & & & & \\
\hline & $(0.592)$ & & & & & & \\
\hline \multirow[t]{2}{*}{ Military interference } & & -0.312 & & & & & \\
\hline & & (0.489) & & & & & \\
\hline \multirow[t]{2}{*}{ Reliability of police } & & & $-1.923 * * *$ & & & & \\
\hline & & & $(0.727)$ & & & & \\
\hline \multirow[t]{2}{*}{ Democratic regime } & & & & 0.267 & & & \\
\hline & & & & (2.091) & & & \\
\hline \multirow[t]{2}{*}{ Age democracy } & & & & & $-0.0985 * * *$ & & \\
\hline & & & & & $(0.0364)$ & & \\
\hline \multirow[t]{2}{*}{ Political rights } & & & & & & 0.668 & \\
\hline & & & & & & $(0.553)$ & \\
\hline \multirow[t]{2}{*}{ Legal rights } & & & & & & & -0.495 \\
\hline & & & & & & & $(0.431)$ \\
\hline Observations & 117 & 108 & 95 & 118 & 118 & 118 & 116 \\
\hline Adjusted-R2 & .469 & .460 & .494 & .459 & .493 & .466 & .467 \\
\hline
\end{tabular}

Dep. variable: informal economy (\% GDP). Constant not reported. s.e. in parentheses. Significance levels: * $10 \%, * * 5 \%, * * * 1 \%$.

Table 3 shows that the higher the impartiality of courts, the judicial independence, and the protection of property rights, the lower the share of informal activities in the economy. The quality of property rights institutions, thus, appears a key determinant of the extent of the informal economy, as well as previous studies have shown it affects long-term growth (see Acemoglu and Johnson, 2005). Countries whose economy is concentrated on the exploitation of natural resources are characterized by a large share of informal economy: this is in line with the concept of "resource 
curse", whereby the excessive reliance by an elite on the revenues from natural resources exploitation is conducive to problems of economic dualism and extractive institutions.

Table 3. Informality and Institution Extractiveness (II)

\begin{tabular}{|c|c|c|c|c|}
\hline & (1) & $(2)$ & (3) & (4) \\
\hline \multirow[t]{2}{*}{ GDP per capita } & -1.839 & -2.248 & -2.045 & $-4.806 * *$ \\
\hline & $(2.292)$ & $(1.957)$ & $(2.284)$ & $(1.972)$ \\
\hline \multirow[t]{2}{*}{ Agriculture VA } & $3.240 *$ & 1.762 & 2.457 & $3.108^{*}$ \\
\hline & $(1.856)$ & $(1.687)$ & $(1.915)$ & $(1.625)$ \\
\hline \multirow[t]{2}{*}{ Population above 65} & 2.813 & 3.187 & 3.369 & $7.281 * * *$ \\
\hline & $(2.948)$ & $(2.449)$ & $(2.936)$ & $(2.366)$ \\
\hline \multirow[t]{2}{*}{ Population in largest city } & $4.408 * *$ & $4.703^{* * *}$ & $4.765^{* * *}$ & $5.066 * * *$ \\
\hline & $(1.683)$ & $(1.560)$ & $(1.683)$ & $(1.564)$ \\
\hline \multirow[t]{2}{*}{ Fractionalization } & 6.839 & $8.222 * *$ & 6.713 & $8.526 * *$ \\
\hline & (4.491) & (3.931) & $(4.492)$ & (3.843) \\
\hline \multirow[t]{2}{*}{ Protestants } & 0.023 & 0.051 & 0.011 & -0.049 \\
\hline & $(0.052)$ & $(0.049)$ & $(0.050)$ & $(0.044)$ \\
\hline \multirow[t]{2}{*}{ Judicial independence } & $-2.158 * * *$ & & & \\
\hline & $(0.606)$ & & & \\
\hline \multirow[t]{2}{*}{ Impartiality of courts } & & $-2.994 * * *$ & & \\
\hline & & $(0.703)$ & & \\
\hline \multirow[t]{2}{*}{ Property rights protection } & & & $-2.885^{* *}$ & \\
\hline & & & $(0.811)$ & \\
\hline \multirow[t]{2}{*}{ Rents from natural resources } & & & & $0.163 * * *$ \\
\hline & & & & $(0.0573)$ \\
\hline Observations & 94 & 108 & 94 & 118 \\
\hline Adjusted-R2 & .521 & .541 & .521 & .496 \\
\hline
\end{tabular}

Dependent variable: informal economy (\% GDP). Constant not reported.

Standard errors in parentheses. Significance levels: * $10 \%, * * 5 \%, * * * 1 \%$.

The results in these tables suggest that the size of the informal economy is notably affected by: i) the reliability of those entrusted with the use of the force; ii) the duration of a (de facto) democratic regime; iii) an extraordinary reliance of the economy on the extraction of natural resources; iv) the quality of "property rights institutions", measured in terms of judicial independence and impartiality, and protection of property rights. This evidence provides support to the hypothesis that institution extractiveness is associated with the size of the informal economy. Besides the individual significance of the parameters, the fit of the estimation improves remarkably when these proxies of the extractiveness of institutions are included in the specification.

It is worth mentioning that the control variables, when significant, have the correct sign: in particular, the proxy of urbanization, the economic structure and the fractionalization of the population. The estimates of the parameters of the variables proxying for the burden of regulation are reported in Table 4. 
Table 4. Informality, Market Regulations and Effectiveness/Efficiency of Institutions

\begin{tabular}{|c|c|c|c|c|c|c|c|c|}
\hline & (1) & $(2)$ & (3) & (4) & $(5)$ & (6) & (7) & $(8)$ \\
\hline \multirow[t]{2}{*}{ GDP per capita } & $-3.617^{*}$ & -3.190 & $-3.488^{*}$ & -2.921 & -3.209 & $-3.644^{*}$ & $-3.550 *$ & $-3.699 *$ \\
\hline & $(2.073)$ & $(2.375)$ & $(2.037)$ & $(2.435)$ & $(2.411)$ & $(1.905)$ & $(1.991)$ & $(1.973)$ \\
\hline \multirow[t]{2}{*}{ Agriculture VA } & $3.361^{*}$ & $4.275^{* *}$ & $3.589 * *$ & $4.492 * *$ & $* 4.185 * *$ & 2.372 & $4.284 * *$ & $3.651^{* *}$ \\
\hline & $(1.760)$ & $(1.896)$ & $(1.714)$ & $(1.948)$ & $(1.977)$ & $(1.698)$ & $(1.746)$ & $(1.696)$ \\
\hline \multirow[t]{2}{*}{ Population above 65} & $4.638 *$ & 4.271 & 4.209 & 4.226 & 3.715 & $4.168^{*}$ & $5.345 * *$ & $5.753 * *$ \\
\hline & $(2.602)$ & (3.188) & $(2.564)$ & (3.163) & $(3.126)$ & $(2.311)$ & $(2.407)$ & $(2.386)$ \\
\hline \multirow{2}{*}{$\begin{array}{l}\text { Population in largest } \\
\text { city }\end{array}$} & $5.148 * *$ & ${ }^{*} 4.555^{* * *}$ & $* 4.621 * * *$ & $* 4.530 * *$ & $* 4.948 * *$ & $* 6.537 * * *$ & $* 5.129 * * *$ & $* 5.456 * * *$ \\
\hline & $(1.674)$ & $(1.788)$ & $(1.653)$ & $(1.798)$ & $(1.824)$ & $(1.642)$ & $(1.660)$ & $(1.663)$ \\
\hline \multirow[t]{2}{*}{ Fractionalization } & $8.861^{* *}$ & 6.806 & $9.021 * *$ & 7.103 & 7.049 & $8.211^{* *}$ & $8.347 * *$ & $8.477^{* *}$ \\
\hline & $(4.226)$ & (4.849) & $(4.150)$ & (4.797) & $(4.780)$ & $(3.852)$ & $(4.058)$ & (3.992) \\
\hline \multirow[t]{2}{*}{ Protestants } & -0.046 & -0.043 & -0.057 & -0.040 & -0.040 & -0.025 & -0.055 & -0.041 \\
\hline & $(0.047)$ & $(0.050)$ & $(0.046)$ & $(0.053)$ & $(0.052)$ & $(0.045)$ & $(0.047)$ & $(0.046)$ \\
\hline \multirow{2}{*}{$\begin{array}{l}\text { Labor market } \\
\text { regulations }\end{array}$} & -1.038 & & & & & & & \\
\hline & $(0.685)$ & & & & & & & \\
\hline \multirow{2}{*}{$\begin{array}{l}\text { Hiring and firing } \\
\text { regulations }\end{array}$} & & 0.631 & & & & & & \\
\hline & & $(0.762)$ & & & & & & \\
\hline \multirow[t]{2}{*}{ Cost worker dismissal } & & -0.209 & & & & & & \\
\hline & & $(0.381)$ & & & & & & \\
\hline \multirow[t]{2}{*}{ Hours regulations } & & -0.897 & $-1.223 * *$ & & & & & \\
\hline & & $(0.588)$ & $(0.495)$ & & & & & \\
\hline \multirow{2}{*}{$\begin{array}{l}\text { Hiring reg. and } \min \\
\text { wage }\end{array}$} & & -0.287 & & & & & & \\
\hline & & $(0.407)$ & & & & & & \\
\hline \multirow[t]{2}{*}{ Bureaucracy costs } & & & & -0.593 & & & & \\
\hline & & & & $(0.836)$ & & & & \\
\hline \multirow[t]{2}{*}{ Administrative burden } & & & & & -1.095 & & & \\
\hline & & & & & $(1.040)$ & & & \\
\hline \multirow[t]{2}{*}{ Time to pay taxes } & & & & & & $4.493 * * *$ & & \\
\hline & & & & & & $(1.489)$ & & \\
\hline \multirow{2}{*}{$\begin{array}{l}\text { Time to resolve } \\
\text { insolvency }\end{array}$} & & & & & & & -0.745 & \\
\hline & & & & & & & $(1.933)$ & \\
\hline \multirow{2}{*}{$\begin{array}{l}\text { Time to enforce a } \\
\text { contract }\end{array}$} & & & & & & & & 2.291 \\
\hline & & & & & & & & $(2.172)$ \\
\hline Observations & 108 & 92 & 108 & 94 & 94 & 116 & 112 & 116 \\
\hline Adjusted-R2 & .470 & .475 & .489 & .454 & .457 & .503 & .471 & .466 \\
\hline
\end{tabular}

Dependent variable: informal economy (\% GDP). Constant not reported. s.e. in parentheses.

Significance levels: * $10 \%, * * 5 \%, * * * 1 \%$.

With the exception of the stringency of the regulations on working hours, which is significantly and positively associated with the size of the informal economy, other labor market regulations and the stringency of other 
standards do not seem significantly associated with the size of the informal activities $^{13}$.

Most of the measures of the effectiveness and efficiency of institutions are also not statistically significant, with the exception of the time needed to pay taxes: the more time-consuming the procedures to comply with the tax requirements, the higher the share of the informal economy. An explanation for these findings can be the following. The fact that the time to enforce a contract or to resolve an insolvency is long does not provide an incentive to keep economic activities informal, because informality provides no benefits in terms of contract enforcement. On the contrary, as informality is often conducive to tax evasion, it does eliminate the problems associated with the compliance with heavy tax procedures.

\subsection{The role of cultural values and trust}

Previous works have shown that culture and trust may affect the size of the informal economy. In what follows we test this hypothesis.

Culture, trust and moral attitudes play a role in the decisions individuals make regarding whether or not to cheat on the State because, as suggested by Hart (1973), individuals make decisions also on the basis of the prevailing norms. Trust has proved to affect both economic development (Knack and Keefer, 1997; Woolcock, 1998; Putnam, 2000; Trigilia, 2001) and individual behavior (Buttler et al., 2016). To a certain extent, formal institutions might influence these factors (Alesina and Giuliano, 2015) and this implies that controlling for them in the empirical analysis absorbs one channel through which institutions indirectly affect the size of the informal economy. It is worth recalling, however, that we are interested in estimating the direct impact of institutions on the size of the informal economy and that their indirect impact falls beyond the scope of the analysis. Hence, in line with our first methodological caveat in Section 2, the inclusion of proxies for culture, trust and generalized morality is warranted even though institutions influence them and thus indirectly impact on the size of the informal economy.

To deal with these variables, we adopt the answers provided to a number of questions in the World Values Survey (WVS), which is the most commonly used tool in cross-country comparisons. As done in the literature (Alesina and Giuliano, 2015), we aggregate the answers at the country level

13 These variables take a maximum value of 10 when the restrictions are low. Accordingly, a negative parameter implies that the higher the regulation, the larger the informal economy. 
to measure values and beliefs that characterize the prevailing culture, trust and attitudes. Data availability reduces the sample size ${ }^{14}$.

To capture deep attitudes not directly connected with economic activity (so as to reduce the risk of reverse causality), we consider the nationwide average responses to the WVS questions regarding the importance of qualities that children should be encouraged to learn at home: tolerance, unselfishness, obedience, responsibility, and hard work. Following the reasoning proposed by Tabellini $(2008 ; 2010)$, these measures can be used to capture various aspects of generalized morality.

\section{Table 5: Informality, Generalized Morality and Civic Sense}

\begin{tabular}{|c|c|c|c|c|c|c|c|c|}
\hline & $(1)$ & (2) & (3) & (4) & (5) & (6) & (7) & $(8)$ \\
\hline \multirow[t]{2}{*}{ GDP per capita } & -5.405 & -5.396 & -5.108 & -6.071 & -5.756 & $-7.063 * *$ & -4.205 & -11.47 \\
\hline & (3.616) & (3.371) & (3.342) & (3.685) & (3.428) & $(2.975)$ & $(3.254)$ & (6.968) \\
\hline \multirow[t]{2}{*}{ Agriculture VA } & 4.525 & 3.756 & 4.724 & 4.292 & 5.093 & 3.991 & $5.354^{*}$ & 1.559 \\
\hline & (3.144) & (3.099) & (3.010) & (3.112) & (3.134) & $(2.648)$ & $(2.920)$ & $(5.213)$ \\
\hline \multirow[t]{2}{*}{ Population above 65} & $10.42^{* *}$ & $9.394^{* *}$ & $13.37 * * *$ & $10.33^{* *}$ & $10.99 * *$ & $* 11.47 * * *$ & *8.893** & $* 9.738 *$ \\
\hline & $(4.236)$ & (4.214) & $(4.530)$ & (4.199) & (4.220) & $(3.632)$ & (3.994) & $(5.472)$ \\
\hline \multirow[t]{2}{*}{ Population in largest city } & $5.278 * *$ & $6.253^{* *}$ & $5.208^{* *}$ & $5.381 * *<$ & $4.820 * *$ & * $5.075^{* *}$ & $5.567 * *$ & $* 4.728$ \\
\hline & $(2.491)$ & (2.413) & (2.264) & $(2.326)$ & (2.370) & $(1.991)$ & $(2.184)$ & (3.119) \\
\hline \multirow[t]{2}{*}{ Fractionalization } & 7.459 & 7.197 & 7.409 & 8.640 & 8.021 & 0.311 & 2.942 & -0.576 \\
\hline & $(6.855)$ & (6.714) & (6.643) & (7.178) & $(6.796)$ & $(6.122)$ & $(6.686)$ & $(10.04)$ \\
\hline \multirow[t]{2}{*}{ Protestants } & -0.049 & -0.075 & -0.045 & -0.047 & -0.061 & -0.005 & -0.046 & -0.029 \\
\hline & $(0.073)$ & $(0.072)$ & $(0.068)$ & $(0.068)$ & $(0.071)$ & $(0.061)$ & $(0.065)$ & $(0.089)$ \\
\hline \multirow[t]{2}{*}{ ICQ: tolerance and respect } & 0.629 & & & & & & & \\
\hline & (18.88) & & & & & & & \\
\hline \multirow[t]{2}{*}{ ICQ: unselfishness } & & -15.09 & & & & & & \\
\hline & & $(12.33)$ & & & & & & \\
\hline \multirow[t]{2}{*}{ ICQ: obedience } & & & 16.54 & & & & & \\
\hline & & & $(10.86)$ & & & & & \\
\hline \multirow[t]{2}{*}{ ICQ: feeling of responsibility } & & & & 8.573 & & & & \\
\hline & & & & (16.61) & & & & \\
\hline \multirow[t]{2}{*}{ ICQ: hard work } & & & & & -6.857 & & & \\
\hline & & & & & (7.676) & & & \\
\hline \multirow{2}{*}{$\begin{array}{l}\text { Justifiable to avoid fare on public } \\
\text { transport }\end{array}$} & & & & & & $7.150 * * *$ & & \\
\hline & & & & & & $(1.870)$ & & \\
\hline \multirow[t]{2}{*}{ Justifiable to cheat on taxes } & & & & & & & $5.310 * *$ & \\
\hline & & & & & & & $(2.264)$ & \\
\hline \multirow[t]{2}{*}{ Justifiable to buy stolen goods } & & & & & & & & 3.234 \\
\hline & & & & & & & & (7.846) \\
\hline Observations & 47 & 47 & 47 & 47 & 47 & 46 & 47 & 28 \\
\hline Adjusted-R2 & .461 & .481 & .491 & .464 & .471 & .612 & .527 & .476 \\
\hline
\end{tabular}

Dependent variable: informal economy (\% GDP). Constant not reported. s.e. in parentheses.

Significance levels: * $10 \%, * * 5 \%, * * * 1 \%$.

14 For the sake of brevity, we do not report the estimations presented in the previous section for the sub-sample of countries for which we have data on culture, trust and sense of belonging. The findings in the previous section hold also for the sub-sample of countries investigated in this section. Results are available upon request. 
We also proxy civic sense by looking at the answers to questions about whether it is justifiable to avoid a fare on public transport, to cheat on taxes, and to buy stolen goods.

The results in Table 5 show that none of the variables capturing the qualities children are expected to learn at home has a statistically significant partial correlation with informality. These findings suggest that crosscountry differences in what the majority perceives as the main qualities a person should exhibit are not relevant determinants of the size of the informal economy. On the contrary, two variables regarding what wrong behavior is considered anyway justifiable have a significant positive impact on the size of the informal economy. If avoiding to pay the fare on public transports or to cheat on taxes is seen as justifiable by the majority, then also undertaking informal (but not illegal) economic activities is considered as justifiable. Notably, this result does not hold for the variable that more directly relates to the sphere of the private economic life, that is buying stolen goods. This result, together with the insignificance of the variables on the qualities children should learn, suggests the existence of a relationship between informality and the way people think of what is due, at least in economic terms, to the public sector they observe and interact with.

We show in Tables 6 and 7 that the inclusion of these significant variables in the baseline specification used for the large sample does not affect the estimated impact of the extractiveness of institutions on the informal economy ${ }^{15}$. Only the inclusion of the variable measuring to what extent is justifiable to avoid a fare on public transports reduces somewhat the statistical significance of the results (Table 6).

Besides culture, also trust and sense of belonging are other important variables to account for. To address the role of trust, we look both at generalized trust (measured as the share of the WVS respondents agreeing with the sentence "Most people can be trusted") and family-related trust (measured as the share of respondents putting absolute faith in their family). In addition to such usual proxies of generalized trust and trust in the family, we also consider measures capturing the extent to which respondents share a sense of belonging to their community: these are derived from the WVS answers to questions about the extent to which they: i) see themselves not as members of their local community, ii) see themselves not as citizens of their nation, and iii) are willing to fight for the country (Table 8).

15 This holds true also for the other insignificant variables proxying for the generalized morality and civic sense. Results are available upon request. 
Table 6: Informality, Civic Sense and Institution Extractiveness

\begin{tabular}{|c|c|c|c|c|c|}
\hline & (1) & (2) & (3) & (4) & (5) \\
\hline GDP per capita & $\begin{array}{l}-3.242 \\
(3.433)\end{array}$ & $\begin{array}{l}-1.340 \\
(3.516)\end{array}$ & $\begin{array}{l}-2.482 \\
(3.095)\end{array}$ & $\begin{array}{l}-1.289 \\
(3.497)\end{array}$ & $\begin{array}{l}-2.853 \\
(3.111)\end{array}$ \\
\hline Agriculture VA & $\begin{array}{c}3.918 \\
(3.097)\end{array}$ & $\begin{array}{c}3.903 \\
(3.021)\end{array}$ & $\begin{array}{c}2.897 \\
(2.868)\end{array}$ & $\begin{array}{l}2.947 \\
(3.092)\end{array}$ & $\begin{array}{c}4.438 \\
(2.773)\end{array}$ \\
\hline Population above 65 & $\begin{array}{l}7.588^{*} \\
(4.084)\end{array}$ & $\begin{array}{c}5.255 \\
(4.175)\end{array}$ & $\begin{array}{c}6.145 \\
(3.855)\end{array}$ & $\begin{array}{c}5.247 \\
(4.147)\end{array}$ & $\begin{array}{c}10.88^{* * *} \\
(3.845)\end{array}$ \\
\hline Population in largest city & $\begin{array}{c}6.153 * * * \\
(2.194)\end{array}$ & $\begin{array}{c}6.122^{* * *} \\
(2.148)\end{array}$ & $\begin{array}{c}6.052^{* * *} \\
(2.039)\end{array}$ & $\begin{array}{c}6.615^{* * *} \\
(2.158)\end{array}$ & $\begin{array}{c}5.341 * * \\
(2.057)\end{array}$ \\
\hline Fractionalization & $\begin{array}{c}2.411 \\
(7.384)\end{array}$ & $\begin{array}{c}3.398 \\
(7.270)\end{array}$ & $\begin{array}{c}6.550 \\
(6.365)\end{array}$ & $\begin{array}{c}4.955 \\
(7.341)\end{array}$ & $\begin{array}{c}8.748 \\
(6.721)\end{array}$ \\
\hline Protestants & $\begin{array}{c}-0.017 \\
(0.0710) \\
\end{array}$ & $\begin{array}{c}0.005 \\
(0.0718) \\
\end{array}$ & $\begin{array}{c}0.068 \\
(0.0742) \\
\end{array}$ & $\begin{array}{c}-0.001 \\
(0.0702) \\
\end{array}$ & $\begin{array}{c}0.024 \\
(0.0678) \\
\end{array}$ \\
\hline Justifiable to cheat on taxes & $\begin{array}{l}4.800^{*} \\
(2.533)\end{array}$ & $\begin{array}{c}5.696 * * \\
(2.386)\end{array}$ & $\begin{array}{c}4.726^{* *} \\
(2.117)\end{array}$ & $\begin{array}{c}5.793 * * \\
(2.371)\end{array}$ & $\begin{array}{c}4.853^{* *} \\
(2.138)\end{array}$ \\
\hline Reliability of police & $\begin{array}{l}-2.007^{*} \\
(1.022)\end{array}$ & & & & \\
\hline Judicial independence & & $\begin{array}{c}-2.139 * * \\
(0.914)\end{array}$ & & & \\
\hline Impartiality of courts & & & $\begin{array}{c}-3.018^{* *} \\
(1.134)\end{array}$ & & \\
\hline Property rights protection & & & & $\begin{array}{c}-3.168^{* *} \\
(1.309)\end{array}$ & \\
\hline Age of democracy & & & & & $\begin{array}{c}-0.119 * * \\
(0.0483) \\
\end{array}$ \\
\hline Observations & 44 & 44 & 47 & 44 & 47 \\
\hline Adjusted-R2 & .557 & .575 & .591 & .579 & .581 \\
\hline
\end{tabular}

Dependent variable: informal economy (\% GDP). Constant not reported. Standard errors in parentheses. Significance levels: $* 10 \%, * * 5 \%, * * * 1 \%$.

In line with previous results in the literature, generalized trust is negatively associated with the extent of the informal economy ${ }^{16}$. Neither particularized trust in the family, nor the variables capturing the sense of belonging to the local and national communities are, instead, statistically significant. The result for particularized trust in the family is interesting as previous works have found a negative correlation between the reliance on family and civic sense, as well as a relationship between family ties and the industrial structure. Moreover, as shown in Table 9, the control for generalized trust in the baseline specification does not affect the estimated impact of the extractiveness of institutions on the informal economy.

The last extension we consider regards another kind of trust, which is particularized trust in various specific institutions. As argued by Alesina and Giuliano (2015), while the responses to questions regarding trust toward public institutions may reflect cultural biases, they may also measure various dysfunctional aspects of formal institutions, among which

16 On the importance of generalized trust, also as a measure of social capital, see Aghion et al. (2010); Algan and Cahuc (2010, 2014); Alesina and Giuliano (2015). 
certainly their extractiveness: when institutions arbitrarily jeopardize what people consider their legitimate share of resources and opportunities, they act in an extractive way and, inevitably, they are distrusted.

\section{Table 7: Informality, Civic Sense and Institution Extractiveness}

\begin{tabular}{|c|c|c|c|c|c|}
\hline & $(1)$ & (2) & (3) & (4) & (5) \\
\hline \multirow[t]{2}{*}{ GDP per capita } & $-5.840^{*}$ & -4.657 & $-5.497 *$ & -4.456 & $-5.817^{*}$ \\
\hline & $(3.411)$ & (3.581) & $(2.996)$ & (3.505) & $(2.946)$ \\
\hline \multirow[t]{2}{*}{ Agriculture VA } & 3.484 & 3.471 & 2.402 & 2.688 & 3.385 \\
\hline & $(2.975)$ & $(2.936)$ & $(2.697)$ & $(2.980)$ & $(2.578)$ \\
\hline \multirow[t]{2}{*}{ Population above 65} & $10.55 * *$ & $9.139 * *$ & $9.247 * *$ & $8.940 * *$ & $12.94 * * *$ \\
\hline & (3.982) & $(4.172)$ & $(3.707)$ & $(4.082)$ & (3.592) \\
\hline \multirow[t]{2}{*}{ Population in largest city } & $5.346 * *$ & $5.265^{* *}$ & $5.473 * * *$ & $5.634 * *$ & $4.940 * *$ \\
\hline & $(2.102)$ & $(2.072)$ & (1.939) & $(2.070)$ & $(1.925)$ \\
\hline \multirow[t]{2}{*}{ Fractionalization } & 1.932 & 3.050 & 3.603 & 4.281 & 5.470 \\
\hline & $(6.875)$ & $(6.912)$ & (6.176) & $(6.946)$ & (6.493) \\
\hline \multirow[t]{2}{*}{ Protestants } & 0.008 & 0.023 & 0.069 & 0.025 & 0.045 \\
\hline & $(0.068)$ & $(0.069)$ & $(0.071)$ & $(0.068)$ & $(0.064)$ \\
\hline \multirow[t]{2}{*}{ Justifiable to avoid fare on public transport } & $5.900 * *$ & $6.114^{* * *}$ & $6.054 * * *$ & $6.190 * * *$ & $6.073^{* * *}$ \\
\hline & $(2.201)$ & $(2.050)$ & $(1.901)$ & $(1.979)$ & $(1.892)$ \\
\hline \multirow[t]{2}{*}{ Reliability of police } & -1.257 & & & & \\
\hline & (1.062) & & & & \\
\hline \multirow[t]{2}{*}{ Judicial independence } & & -1.358 & & & \\
\hline & & (0.941) & & & \\
\hline \multirow[t]{2}{*}{ Impartiality of courts } & & & $-2.129 *$ & & \\
\hline & & & $(1.128)$ & & \\
\hline \multirow[t]{2}{*}{ Protection } & & & & $-2.257^{*}$ & \\
\hline & & & & $(1.308)$ & \\
\hline \multirow[t]{2}{*}{ Age of democracy } & & & & & $-0.0918^{*}$ \\
\hline & & & & & $(0.0477)$ \\
\hline Observations & 43 & 43 & 46 & 43 & 46 \\
\hline Adjusted-R2 & .598 & .606 & .636 & .615 & .638 \\
\hline
\end{tabular}

Dependent variable: informal economy (\% GDP). Constant not reported.

Standard errors in parentheses. Significance levels: $* 10 \%, * * 5 \%, * * * 1 \%$.

We thus include variables capturing the share of the respondents that distrust labor unions, police, parliament, civil services, government, political parties, and justice system. We also consider a variable measuring the share of the population dissatisfied with the way democracy develops.

The results, summarized in Table 10, are remarkably consistent and all measures are strongly correlated with the size of the informal economy. Again, we believe that this provides further evidence of the importance of the perceived functioning of institutions, besides their merely formal setting, for the extent of the informal economy. 
Table 8: Informality, Trust and Sense of Belonging

\begin{tabular}{|c|c|c|c|c|c|}
\hline & $(1)$ & $(2)$ & (3) & (4) & $(5)$ \\
\hline \multirow[t]{2}{*}{ GDP per capita } & -5.572 & $-5.895^{*}$ & -4.634 & -4.592 & -5.696 \\
\hline & (3.519) & (3.218) & (3.588) & (3.575) & (3.539) \\
\hline \multirow[t]{2}{*}{ Agriculture VA } & 3.947 & 4.663 & 4.620 & 4.552 & 4.364 \\
\hline & (3.130) & $(2.975)$ & (3.401) & (3.473) & (3.349) \\
\hline \multirow[t]{2}{*}{ Population above 65} & $11.10 * *$ & $13.20 * * *$ & $10.33 * *$ & $10.46 * *$ & $10.97 * *$ \\
\hline & $(4.127)$ & $(4.029)$ & $(4.376)$ & (4.199) & $(4.805)$ \\
\hline \multirow[t]{2}{*}{ Population in largest city } & $6.482 * * *$ & $3.935^{*}$ & $6.089 * *$ & $6.035^{* *}$ & $5.311 * *$ \\
\hline & $(2.378)$ & (2.214) & $(2.459)$ & $(2.384)$ & $(2.394)$ \\
\hline \multirow[t]{2}{*}{ Fractionalization } & 3.248 & 4.657 & 7.602 & 7.694 & 7.340 \\
\hline & $(6.843)$ & $(6.561)$ & $(6.841)$ & $(6.782)$ & (7.088) \\
\hline \multirow[t]{2}{*}{ Protestants } & -0.080 & 0.085 & -0.034 & -0.038 & -0.044 \\
\hline & $(0.068)$ & $(0.082)$ & $(0.0734)$ & $(0.081)$ & $(0.075)$ \\
\hline \multirow[t]{2}{*}{ Trust in family } & -28.94 & & & & \\
\hline & $(18.76)$ & & & & \\
\hline \multirow[t]{2}{*}{ Generalized trust } & & $-32.96 * *$ & & & \\
\hline & & $(12.25)$ & & & \\
\hline \multirow[t]{2}{*}{ No member of local community } & & & 0.598 & & \\
\hline & & & $(10.35)$ & & \\
\hline \multirow[t]{2}{*}{ No citizen of the country } & & & & -0.928 & \\
\hline & & & & $(10.87)$ & \\
\hline \multirow[t]{2}{*}{ Willingness to fight for country } & & & & & 0.762 \\
\hline & & & & & $(12.34)$ \\
\hline Observations & 44 & 46 & 41 & 41 & 46 \\
\hline Adjusted-R2 & .496 & .548 & .457 & .457 & .463 \\
\hline
\end{tabular}

Dependent variable: informal economy (\% GDP). Constant not reported. Standard errors in parentheses. Significance levels: * $10 \%, * * 5 \%, * * * 1 \%$. 
Table 9: Informality, Generalized Trust and Institution Extractiveness

\begin{tabular}{|c|c|c|c|c|c|}
\hline & (1) & (2) & (3) & (4) & (5) \\
\hline \multirow[t]{2}{*}{ GDP per capita } & -4.008 & -2.509 & -4.223 & -2.285 & -4.734 \\
\hline & (3.361) & (3.624) & (3.184) & (3.512) & (3.105) \\
\hline \multirow[t]{2}{*}{ Agriculture VA } & 4.018 & 5.023 & 2.655 & 3.909 & 3.102 \\
\hline & $(3.202)$ & (3.172) & (3.006) & (3.209) & $(2.914)$ \\
\hline \multirow[t]{2}{*}{ Population above 65} & $10.29 * *$ & $9.155^{* *}$ & $10.12 * *$ & $8.903 * *$ & $14.45 * * *$ \\
\hline & $(4.082)$ & (4.393) & $(4.129)$ & $(4.242)$ & $(3.872)$ \\
\hline \multirow[t]{2}{*}{ Population in largest city } & $4.354^{*}$ & $4.033^{*}$ & $4.678 * *$ & $4.409 *$ & $4.049 *$ \\
\hline & (2.231) & (2.259) & $(2.151)$ & (2.232) & (2.107) \\
\hline \multirow[t]{2}{*}{ Fractionalization } & 6.157 & 6.471 & 7.893 & 8.321 & 11.82 \\
\hline & $(6.940)$ & (7.119) & $(6.472)$ & (7.100) & (7.015) \\
\hline \multirow[t]{2}{*}{ Protestants } & 0.146 & 0.136 & $0.149^{*}$ & $0.154^{*}$ & $0.143^{*}$ \\
\hline & $(0.088)$ & $(0.090)$ & $(0.085)$ & $(0.089)$ & $(0.083)$ \\
\hline \multirow[t]{2}{*}{ Generalized trust } & $-32.33^{* *}$ & $-30.87 * *$ & $-25.40 * *$ & $-33.82 * *$ & $-28.75^{* *}$ \\
\hline & $(12.94)$ & $(13.59)$ & $(12.28)$ & $(12.78)$ & $(11.81)$ \\
\hline \multirow[t]{2}{*}{ Reliability of police } & $-2.219 * *$ & & & & \\
\hline & $(1.062)$ & & & & \\
\hline \multirow[t]{2}{*}{ Judicial independence } & & $-1.650 *$ & & & \\
\hline & & $(0.974)$ & & & \\
\hline \multirow[t]{2}{*}{ Impartiality of courts } & & & $-2.524 * *$ & & \\
\hline & & & $(1.203)$ & & \\
\hline \multirow[t]{2}{*}{ Property rights protection } & & & & $-2.814^{* *}$ & \\
\hline & & & & $(1.329)$ & \\
\hline \multirow[t]{2}{*}{ Age of democracy } & & & & & $-0.119 * *$ \\
\hline & & & & & $(0.0532)$ \\
\hline Observations & 43 & 43 & 46 & 43 & 46 \\
\hline Adjusted-R2 & .588 & .572 & .585 & .590 & .591 \\
\hline
\end{tabular}

Dependent variable: informal economy (\% GDP). Constant not reported. Standard errors in parentheses. Significance levels: $* 10 \%, * * 5 \%, * * * 1 \%$. 
Table 10: Informality and Distrust in Formal Institutions

\begin{tabular}{|c|c|c|c|c|c|c|c|c|}
\hline & (1) & (2) & (3) & (4) & (5) & (6) & (7) & (8) \\
\hline GDP per capita & $\begin{array}{l}-5.656^{*} \\
(3.218)\end{array}$ & $\begin{array}{l}-4.624 \\
(3.019)\end{array}$ & $\begin{array}{l}-4.875 \\
(3.130)\end{array}$ & $\begin{array}{l}-5.358 \\
(3.228)\end{array}$ & $\begin{array}{l}-4.354 \\
(3.348)\end{array}$ & $\begin{array}{l}-5.048 \\
(3.101)\end{array}$ & $\begin{array}{l}-5.388 \\
(3.302)\end{array}$ & $\begin{array}{c}-4.616 \\
(5.325)\end{array}$ \\
\hline Agriculture VA & $\begin{array}{c}4.610 \\
(2.898)\end{array}$ & $\begin{array}{c}3.783 \\
(2.723)\end{array}$ & $\begin{array}{l}5.619^{*} \\
(2.843)\end{array}$ & $\begin{array}{c}4.810 \\
(2.911)\end{array}$ & $\begin{array}{l}5.278^{*} \\
(2.999)\end{array}$ & $\begin{array}{c}6.209 * * \\
(2.847)\end{array}$ & $\begin{array}{c}4.102 \\
(2.972)\end{array}$ & $\begin{array}{c}5.731 \\
(4.894)\end{array}$ \\
\hline Population above 65 & $\begin{array}{l}7.128^{*} \\
(4.181)\end{array}$ & $\begin{array}{c}5.740 \\
(3.969)\end{array}$ & $\begin{array}{c}6.745 \\
(4.075)\end{array}$ & $\begin{array}{l}7.917 * \\
(4.105)\end{array}$ & $\begin{array}{c}5.514 \\
(4.727)\end{array}$ & $\begin{array}{l}7.807 * \\
(3.944)\end{array}$ & $\begin{array}{l}7.665^{*} \\
(4.487)\end{array}$ & $\begin{array}{c}5.902 \\
(5.579)\end{array}$ \\
\hline Population in largest city & $\begin{array}{c}3.549 \\
(2.306)\end{array}$ & $\begin{array}{r}4.789 * * \\
(2.070)\end{array}$ & $\begin{array}{l}3.919 * \\
(2.190)\end{array}$ & $\begin{array}{c}3.716 \\
(2.298)\end{array}$ & $\begin{array}{c}4.771^{* *} \\
(2.295)\end{array}$ & $\begin{array}{c}2.976 \\
(2.246)\end{array}$ & $\begin{array}{l}4.465^{*} \\
(2.283)\end{array}$ & $\begin{array}{l}5.621^{*} \\
(2.696)\end{array}$ \\
\hline Fractionalization & $\begin{array}{c}3.702 \\
(6.599)\end{array}$ & $\begin{array}{c}0.938 \\
(6.641)\end{array}$ & $\begin{array}{c}3.883 \\
(6.729)\end{array}$ & $\begin{array}{c}4.528 \\
(6.554)\end{array}$ & $\begin{array}{c}4.545 \\
(7.701)\end{array}$ & $\begin{array}{c}4.078 \\
(6.654)\end{array}$ & $\begin{array}{c}2.972 \\
(7.266)\end{array}$ & $\begin{array}{c}-4.826 \\
(9.225)\end{array}$ \\
\hline Protestants & $\begin{array}{c}0.001 \\
(0.069) \\
\end{array}$ & $\begin{array}{c}0.012 \\
(0.064) \\
\end{array}$ & $\begin{array}{c}0.007 \\
(0.066) \\
\end{array}$ & $\begin{array}{c}-0.011 \\
(0.068) \\
\end{array}$ & $\begin{array}{c}-0.028 \\
(0.068) \\
\end{array}$ & $\begin{array}{c}0.000 \\
(0.065) \\
\end{array}$ & $\begin{array}{l}-0.011 \\
(0.070) \\
\end{array}$ & $\begin{array}{c}0.146 \\
(0.150) \\
\end{array}$ \\
\hline Distrust in labor unions & $\begin{array}{l}12.41^{* *} \\
(5.287)\end{array}$ & & & & & & & \\
\hline Distrust in police & & $\begin{array}{c}13.96 * * * \\
(3.890)\end{array}$ & & & & & & \\
\hline Distrust in Parliament & & & $\begin{array}{c}10.74 * * * \\
(3.535)\end{array}$ & & & & & \\
\hline Distrust in civil services & & & & $\begin{array}{c}10.54 * * \\
(4.634)\end{array}$ & & & & \\
\hline Distrust in government & & & & & $\begin{array}{c}9.722 * * \\
(4.225)\end{array}$ & & & \\
\hline Distrust in political parties & & & & & & $\begin{array}{c}13.40 * * * \\
(4.230)\end{array}$ & & \\
\hline Distrust in courts & & & & & & & $\begin{array}{l}7.481^{*} \\
(4.272)\end{array}$ & \\
\hline Dissatisfaction with democracy & & & & & & & & $\begin{array}{c}15.78 * * \\
(5.384) \\
\end{array}$ \\
\hline Observations & 47 & 46 & 46 & 47 & 45 & 46 & 45 & 21 \\
\hline Adjusted-R2 & .527 & .593 & .562 & .524 & .514 & .569 & .495 & .579 \\
\hline
\end{tabular}

Dependent variable: informal economy (\% GDP). Constant not reported. s.e. in parentheses.

Significance levels: * $10 \%, * * 5 \%, * * * 1 \%$.

\subsection{Results for non-OECD countries}

It could be argued that the degree of cross-country heterogeneity in the impact of institutions on the size of informal economic activities warrants the distinction between developed and developing countries. Notwithstanding the controls inserted in the baseline regressions to account for this, there might be country-specific factors that cannot be fully controlled for ${ }^{17}$.

As a robustness check, thus, we address this concern by replicating the main estimations on a sub-sample of countries that are not members of the OECD. The results, reported in Tables 11-13, suggest that almost all the findings for the entire large sample are qualitatively valid also for the subsample of non-OECD countries: all the coefficients for the variables

17 We would like to thank an anonymous reviewer for pointing this out. 
capturing a dimension of the quality of institutions have the same sign and similar size. Unsurprisingly, given the lower number of observations, the reduced variability of the explanatory variables in the restricted sample of more homogeneous countries and the higher collinearity between independent variables in the subsample, a few coefficients appear not to be statistically significant. This notwithstanding, the overall explanatory power of the models remains satisfactory and the significance of the institutional variables is preserved.

Table 11: Informality and Institution Extractiveness in Non-OECD Countries

\begin{tabular}{|c|c|c|c|c|c|c|c|}
\hline & $(1)$ & (2) & (3) & $(4)$ & (5) & $(6)$ & $(7)$ \\
\hline \multirow[t]{2}{*}{ GDP per capita } & -2.192 & -2.130 & -1.157 & -2.015 & -2.079 & -2.104 & -2.696 \\
\hline & (2.253) & (2.595) & (3.024) & (2.247) & (2.258) & $(2.260)$ & $(2.324)$ \\
\hline \multirow[t]{2}{*}{ Agriculture VA } & 3.199 & 3.490 & 3.725 & 3.067 & 3.152 & 3.133 & 3.293 \\
\hline & $(2.003)$ & (2.159) & $(2.566)$ & $(2.003)$ & $(2.004)$ & $(2.005)$ & $(2.063)$ \\
\hline \multirow[t]{2}{*}{ Population above 65} & $7.523 * * *$ & $6.533^{* *}$ & 4.495 & $5.655 * *$ & $6.116 * *$ & $6.498 * *$ & $7.624 * * *$ \\
\hline & $(2.749)$ & $(3.030)$ & (3.717) & $(2.550)$ & $(2.461)$ & $(2.605)$ & $(2.782)$ \\
\hline \multirow[t]{2}{*}{ Population in largest city } & $5.579 * * *$ & $5.682 * * *$ & $5.749 * *$ & $5.361 * * *$ & $5.495 * * *$ & $5.467 * * *$ & $5.583 * * *$ \\
\hline & (1.999) & $(2.146)$ & $(2.367)$ & $(1.986)$ & $(2.008)$ & $(1.991)$ & (2.029) \\
\hline \multirow[t]{2}{*}{ Fractionalization } & $10.96 * *$ & $9.606^{*}$ & 7.871 & $9.253^{*}$ & $9.577^{*}$ & $9.944 * *$ & $10.01 * *$ \\
\hline & $(5.005)$ & $(5.436)$ & (6.378) & (4.871) & $(4.860)$ & $(4.978)$ & $(5.011)$ \\
\hline \multirow[t]{2}{*}{ Protestants } & -0.021 & -0.014 & -0.065 & -0.019 & -0.023 & -0.018 & -0.004 \\
\hline & $(0.083)$ & $(0.090)$ & $(0.100)$ & $(0.082)$ & $(0.082)$ & $(0.083)$ & $(0.085)$ \\
\hline \multirow[t]{2}{*}{ Executive constraints } & -0.490 & & & & & & \\
\hline & $(0.657)$ & & & & & & \\
\hline \multirow[t]{2}{*}{ Military interference } & & -0.185 & & & & & \\
\hline & & $(0.557)$ & & & & & \\
\hline \multirow[t]{2}{*}{ Reliability of police } & & & -1.367 & & & & \\
\hline & & & $(0.989)$ & & & & \\
\hline \multirow[t]{2}{*}{ Democratic regime } & & & & 1.576 & & & \\
\hline & & & & (2.258) & & & \\
\hline \multirow[t]{2}{*}{ Age democracy } & & & & & 0.0190 & & \\
\hline & & & & & $(0.0833)$ & & \\
\hline \multirow[t]{2}{*}{ Political rights } & & & & & & 0.207 & \\
\hline & & & & & & $(0.637)$ & \\
\hline \multirow[t]{2}{*}{ Legal rights } & & & & & & & -0.279 \\
\hline & & & & & & & $(0.510)$ \\
\hline Observations & 90 & 81 & 68 & 91 & 91 & 91 & 89 \\
\hline Adjusted-R2 & .247 & .186 & .153 & .241 & .237 & .238 & .223 \\
\hline
\end{tabular}

Dep. variable: informal economy (\% GDP). Constant not reported. s.e. in parentheses.

Significance levels: * $10 \%, * * 5 \%, * * * 1 \%$. 
Table 12: Informality and Institution Extractiveness in Non-OECD Countries

\begin{tabular}{lcccc}
\hline & $\mathbf{( 1 )}$ & $\mathbf{( 2 )}$ & $\mathbf{( 3 )}$ & $\mathbf{( 4 )}$ \\
\hline GDP per capita & -0.432 & -1.503 & -0.842 & -3.682 \\
& $(3.000)$ & $(2.417)$ & $(2.995)$ & $(2.346)$ \\
Agriculture VA & 3.959 & 2.125 & 3.269 & 2.890 \\
& $(2.447)$ & $(2.131)$ & $(2.539)$ & $(1.961)$ \\
Population above 65 & 3.664 & 4.616 & 4.175 & $8.686^{* * *}$ \\
& $(3.715)$ & $(2.988)$ & $(3.696)$ & $(2.681)$ \\
Population in largest city & $4.932^{* *}$ & $5.337^{* *}$ & $5.351^{* *}$ & $5.701^{* * *}$ \\
& $(2.326)$ & $(2.057)$ & $(2.325)$ & $(1.947)$ \\
Fractionalization & 8.473 & $9.622^{*}$ & 8.261 & $9.723^{* *}$ \\
& $(6.304)$ & $(5.180)$ & $(6.315)$ & $(4.747)$ \\
Protestants & 0.012 & 0.026 & -0.001 & -0.018 \\
& $(0.101)$ & $(0.085)$ & $(0.100)$ & $(0.080)$ \\
\hline Judicial independence & $-1.657^{* *}$ & & & \\
& $(0.802)$ & & & \\
Impartiality of courts & & $-2.413^{* *}$ & & \\
& & $(0.921)$ & & \\
Property rights protection & & & $-2.120^{* *}$ & $(1.056)$ \\
& & & & $0.128^{* *}$ \\
Rents from natural resources & & & & $(0.0637)$ \\
\hline Observations & & & 61 & .272 \\
\hline Adjusted-R2 & .182 & .255 & .179 & \\
\hline
\end{tabular}

Dep. variable: informal economy (\% GDP). Constant not reported.

Standard errors in parentheses. Significance levels: * $10 \%, * * 5 \%, * * * 1 \%$. 
Table 13: Informality, Burden of Regulation and Effectiveness/Efficiency of Institutions in Non-OECD Countries

\begin{tabular}{|c|c|c|c|c|c|c|c|c|}
\hline & (1) & (2) & (3) & (4) & (5) & (6) & (7) & (8) \\
\hline \multirow[t]{2}{*}{ GDP per capita } & -2.333 & -1.291 & -2.401 & -0.879 & -1.123 & -2.698 & -2.004 & -2.753 \\
\hline & (2.501) & (3.105) & $(2.431)$ & (3.090) & $(3.092)$ & $(2.253)$ & (2.308) & (2.322) \\
\hline \multirow[t]{2}{*}{ Agriculture VA } & 3.402 & $4.706^{*}$ & 3.322 & $4.676^{*}$ & $4.394 *$ & 2.409 & $4.620 * *$ & 3.216 \\
\hline & $(2.164)$ & $(2.505)$ & $(2.098)$ & (2.507) & $(2.574)$ & (2.048) & $(2.082)$ & $(2.063)$ \\
\hline \multirow[t]{2}{*}{ Population above 65} & $6.410 * *$ & 5.075 & $6.401 * *$ & 5.115 & 4.676 & $5.863^{* *}$ & $6.726 * *$ & $7.741 * * *$ \\
\hline & $(3.034)$ & (3.914) & $(2.942)$ & (3.852) & (3.796) & $(2.684)$ & (2.696) & $(2.766)$ \\
\hline \multirow[t]{2}{*}{ Population in largest city } & $5.743 * * *$ & $5.128 * *$ & $4.943 * *$ & $5.294 * *$ & $5.472 * *$ & $7.053 * * *$ & $5.683 * * *$ & $5.863 * * *$ \\
\hline & $(2.143)$ & $(2.496)$ & $(2.114)$ & (2.397) & $(2.413)$ & $(2.083)$ & (2.049) & $(2.047)$ \\
\hline \multirow[t]{2}{*}{ Fractionalization } & $9.504^{*}$ & 7.391 & $9.576^{*}$ & 8.834 & 8.325 & $8.911^{*}$ & $9.186^{*}$ & $9.281^{*}$ \\
\hline & (5.432) & $(6.841)$ & (5.258) & (6.590) & $(6.503)$ & $(4.817)$ & $(4.960)$ & (4.938) \\
\hline \multirow[t]{2}{*}{ Protestants } & -0.016 & -0.022 & -0.033 & -0.040 & -0.044 & -0.014 & -0.044 & -0.014 \\
\hline & $(0.088)$ & $(0.103)$ & $(0.084)$ & $(0.101)$ & $(0.101)$ & $(0.081)$ & $(0.083)$ & $(0.083)$ \\
\hline \multirow[t]{2}{*}{ Labor market regulations } & -0.453 & & & & & & & \\
\hline & $(0.883)$ & & & & & & & \\
\hline \multirow[t]{2}{*}{ Hiring and firing regulations } & & 0.600 & & & & & & \\
\hline & & $(1.071)$ & & & & & & \\
\hline \multirow[t]{2}{*}{ Cost worker dismissal } & & -0.0789 & & & & & & \\
\hline & & $(0.496)$ & & & & & & \\
\hline \multirow[t]{2}{*}{ Hours regulations } & & -0.915 & $-1.351 * *$ & & & & & \\
\hline & & (0.809) & $(0.635)$ & & & & & \\
\hline \multirow[t]{2}{*}{ Hiring regulations and min wage } & & -0.184 & & & & & & \\
\hline & & (0.498) & & & & & & \\
\hline \multirow[t]{2}{*}{ Bureaucracy costs } & & & & -0.608 & & & & \\
\hline & & & & (1.067) & & & & \\
\hline \multirow[t]{2}{*}{ Administrative burden } & & & & & -0.851 & & & \\
\hline & & & & & $(1.251)$ & & & \\
\hline \multirow[t]{2}{*}{ Time to pay taxes } & & & & & & $3.856 * *$ & & \\
\hline & & & & & & $(1.793)$ & & \\
\hline \multirow[t]{2}{*}{ Time to resolve insolvency } & & & & & & & $-4.739 *$ & \\
\hline & & & & & & & (2.713) & \\
\hline \multirow[t]{2}{*}{ Time to enforce a contract } & & & & & & & & 1.926 \\
\hline & & & & & & & & $(2.573)$ \\
\hline Observations & 81 & 65 & 81 & 67 & 67 & 89 & 85 & 89 \\
\hline Adjusted-R2 & 0.187 & 0.126 & 0.232 & 0.128 & 0.130 & 0.262 & 0.261 & 0.225 \\
\hline
\end{tabular}

Dep. variable: informal economy (\% GDP). Constant not reported. s.e. in parentheses.

Standard errors in parentheses. Significance levels: * $10 \%, * * 5 \%, * * * 1 \%$.

\section{Conclusions}

This work investigates whether and to what extent the extractiveness of formal institutions directly influences the size of informal economic activities. This important aspect of the actual functioning of the institutional framework has never been studied before in socio-economic literature on informality, notwithstanding the evidence in favor of its impact on other important aspects of the development process (Acemoglu et al., 2001, 2005; Acemoglu and Robinson, 2012). 
To test this hypothesis, we employ several variables proxying for their extractiveness as well as other distinct features. As we aim to cover a set of countries larger than the samples studied so far, we start by concentrating on indicators available for more than 90 countries and then consider additional estimations (accounting for various culture, trust and generalized morality) for a smaller group of about 50 countries. In the analysis we do not resort to broad institutional measures for the quality of institutions, such as the well-known and widely used World Governance Indicators, as such synthetic measures tend to subsume and average out very different institutional aspects we are instead interested in disentangling.

Our empirical results suggest that institution extractiveness is a significant determinant of the size of the informal economy whereas, as found also in previous studies, only a limited number of variables proxying for the effectiveness and efficiency of institutions appear to impact on informality. While we find no evidence that cultural and religious traits do play a relevant impact, the attitude of people to consider as justifiable avoiding to pay the fare on public transports and cheating on taxes is correlated with the size of informal economy, thereby suggesting the existence of a relationship between informality and what people believe to owe to the public sector.

In line with previous results, we also find that the greater the generalized trust the lower the extent of the informal economy. Neither particularized trust in the family, nor the sense of belonging to the local and national communities are significantly associated with informality. Notably, we find evidence that informality is associated with the lack of trust in various kinds of formal institutions and we believe that this reinforces our findings regarding the impact of the perceived extractiveness of institutions on informality.

By showing the impact of the extractiveness of institutions, this work helps to explain why various countries exhibit low levels of informality notwithstanding very high taxation and stringent regulation: burdensome taxes and regulations, the reasoning goes, risk pushing agents into informality more in the presence of extractive than inclusive institutions. This is in line with the theoretical work by Acemoglu (2005), who identifies "consensually-strong State equilibria", whereby a State is politically weak but manages to impose high taxes because a sufficient fraction of the proceeds is invested in public goods to the benefit of the population.

This approach may also help to account for the fact, pointed out by Friedman et al. (2000), that tax rates and revenues exhibit a negative partial correlation with the share of the informal economy once some controls for the quality of institutions are introduced. That taxes and regulatory burdens are negatively correlated with the informal economy would otherwise 
appear a counter-intuitive finding for those embracing a purely neoliberal approach (see, for instance, De Soto 1989), whereby individuals react to restrictive norms by moving as much activity as possible into the informal economy. In fact, this observed result is less surprising once the dichotomy between inclusive and extractive institutions is taken into consideration.

Besides filling a gap in the socio-economic literature on informality, our findings pave the way to further analyses on smaller samples of countries or case studies with a view to investigating more directly the specific channels through which extractive institutions affect the decision to undertake informal activities. Finally, this study may inform future research on the relationship between extractive/inclusive institutions and specific types of informal economic activities (e.g., for profit vs. not for profit).

\section{References}

Acemoglu, D., 2005. Politics and economics in weak and strong states. Journal of Monetary Economics 52 (7), 1199-1226.

Acemoglu, D., Johnson, S., 2005. Unbundling institutions. Journal of Political Economy 113 (5), 949-995.

Acemoglu, D., S. Johnson, Robinson, J.A., 2001. The colonial origins of comparative development: An empirical investigation. American Economic Review 91 (5),1369-1401.

Acemoglu, D., S. Johnson, Robinson, J.A., 2005. Institutions as a fundamental cause of long-run growth. In P. Aghion and S. Durlauf (Eds.), Handbook of Economic Growth, Chapter 6. Amsterdam: Elsevier.

Acemoglu, D., Robinson, J., 2012. Why Nations Fail: The Origins of Power, Prosperity Poverty. London: Prole Books Ltd.

Adriaenssens, S., Hendrickx, J., 2015. Can informal economic activities be explained by social and institutional factors? A comparative analysis. Socio-Economic Review 13 (4), 627-649.

Aghion, P., Y. Algan, Cahuc, P., 2011. Civil society and the state: the interplay between cooperation and minimum wage regulation. Journal of the European Economic Association 9 (1), 3-42.

Aghion, P., Y. Algan, P. Cahuc, Shleifer, A., 2010. Regulation and distrust. The Quarterly Journal of Economics 125 (3), 1015-1049.

Alesina, A., Giuliano, P., 2015. Culture and institutions. Journal of Economic Literature LIII, 898-944. 
Algan, Y., Cahuc, P., 2010. Inherited trust and growth. American Economic Review 100 (5), 2060-92

Algan, Y., Cahuc, P., 2014. Trust, growth, well-being: New evidence and policy implications. In P. Aghion and S. N. Durlauf (Eds.), Handbook of Economic Growth, Volume 2A, Chapter 2, pp. 49-120. Amsterdam: Elsevier.

Andrews, D., A. C. Sanchez, Johansson, A., 2011. Towards a better understanding of the informal economy. OECD Economics Department Working Papers 873, OECD.

Berggren, N., C. Bjrnskov, Lipka, D., 2015. Legitimacy and the cost of government. Public Choice 162 (3), 307-328.

Bhattacharya, P. C., 2011. Informal sector, income inequality and economic development. Economic Modelling 28 (3), 820-830.

Boeke, J. H., 1942. Economies and Economic Policy in Dual Societies. Harlem: Tjeenk Willnik.

Boeke, J. H.,1953. Economics and Economic Policy of Dual Societies as Exemplified by Indonesia. New York: Institute of Pacific Relations.

Bortolotti, B., C. Cambini, Rondi, L., 2013. Reluctant regulation. Journal of Comparative Economics 41 (3), 804-828.

Bose, P., 1998. Formal-informal sector interaction in rural credit markets. Journal of Development Economics 56 (2), 265-280.

Buehn, A., Schneider, F., 2012. Shadow economies around the world: novel insights, accepted knowledge, new estimates. International Tax and Public Finance 19 (1), 139-171.

Buttler, J. V., L. Guiso, Giuliano, P., 2016. The right amount of trust. Journal of the European Economic Association 14 (5), 1155-1180.

Centeno, M., Portes, A., 2006. The informal economy in the shadow of the state. In P. Fernandez-Kelly and J. Shefner (Eds.), Out of the shadows. Political action and informal economy in Latin America, pp. 23-49. Pennsylvania: Pennsylvania University Press.

Charmes, J., 2012. The informal economy worldwide: trends and characteristics. Margin: The Journal of Applied Economic Research 6 (2), 103-132.

Cheibub, J., J. Gandhi, Vreeland, J., 2010. Democracy and dictatorship revisited. Public Choice 143 (1), 67-101. 
Chen, M. A., 2006. Rethinking the informal economy: Linkages with the formal economy and the formal regulatory environment. In B. GuhaKhasnobis, R. Kanbur, E. Ostrom (Eds.), Linking the Formal and Informal Economy, pp. 75-93. New York: Oxford University Press.

Chong, A., Gradstein, M., 2007. Inequality and informality. Journal of Public Economics 91 (1-2), 159-179.

Coletto, D., 2010. The informal economy and employment in Brazil. New York: Palgrave Macmillan.

Dabla-Norris, E., M. Gradstein, Inchauste, G., 2008. What causes firms to hide output? The determinants of informality. Journal of Development Economics 85 (1-2), 1-27.

De Soto, H., 1989. The Other Path. New York: Basic Book.

Easterly, W., Levine, R., 2003. Tropics, germs, crops: how endowments influence economic development. Journal of Monetary Economics 50 (1), 3-39.

Feige, E. L., 1990. Defining and estimating underground and informal economies: The new institutional economics approach. World Development 18 (7), 989-1002.

Feige, E. L., 1997. Underground activity and institutional change: productive, protective and predatory behavior in transition economies. In J. Nelson, C. Tilly, L. Walker (Eds.), Transforming Post-Communist Political Economies., pp. 21-35. Washington DC: National Academy.

Friedman, E., S. Johnson, D. Kaufmann, Zoido-Lobaton, P., 2000. Dodging the grabbing hand: the determinants of unofficial activity in 69 countries. Journal of Public Economics 76 (3), 459-493.

Geertz, C., 1963. Peddlers and princes: Social development and economic change in two Indonesian towns. Comparative Studies of New Nations. Chicago: Chicago University Press.

Giles, D.E.A., 1999. Measuring the hidden economy: Implications for econometric modelling. Economic Journal 109 (456), 370-380.

Glaeser, E., R. L. Porta, F. L. de Silanes, Schleifer, A., 2004. Do institutions cause growth? Journal of Economics Growth 9, 271-303.

Grosjean, P., F. Rick, Senik, C., 2013. Learning, political attitudes and crises: Lessons from transition countries. Journal of Comparative Economics 41, 490-505.

Guha-Khasnobis, B., R. Kanbur, Ostrom, E., 2006. Linking the formal and informal economy. New York: Oxford University Press. 
Harris, J. R., Todaro, M.P., 1970. Migration, unemployment and development: A two-sector analysis. American Economic Review 60, 126-142.

Hart, K. 1973. Informal income opportunities and urban employment in Ghana. Journal of Modern African Studies 11, 61-89.

Hart, K., 2010. Informal economy. In K. Hart, J. L. Laville, A. Cattani (Eds.), The Human Economy. Cambridge, UK: Polity.

Hirschman, A.O., 1957. Investment policies and dualism in underdeveloped countries. The American Economic Review 47 (5), 550570.

Hirschman, A.O., 1970. Exit, Voice and Loyalty. Cambridge: Harvard University Press.

Ihrig, J., Moe, K. S., 2004. Lurking in the shadows: the informal sector and government policy. Journal of Development Economics 73 (2), 541-557.

ILO, 2002. Decent work and the informal economy. Geneva: ILO Department of Statistics.

ILO, 2011. Statistical update on employment in the informal economy. Geneva: ILO Department of Statistics.

ILO-WIEGO, 2013. Women and Men in the Informal Economy: A Statistical Picture. Geneva: ILO.

Jutting, J., De Laiglesia, J., 2009. Is informal normal? Towards more and better jobs in developing countries. Paris: OECD Publishing.

Kanbur, R., 2015. Informality: causes, consequences and policy responses. CEPR Discussion paper 10509, Centre for Economic Policy Research.

Kar, S., Marjit, S., 2009. Urban informal sector and poverty. International Review of Economics \& Finance 18 (4), 631-642.

Knack, S., Keefer, P., 1997. Does social capital have an economic payoff? A cross-country investigation. The Quarterly Journal of Economics 112 (4), 1251-1288.

Kus, B., 2010. Regulatory governance and the informal economy: crossnational comparisons. Socio-Economic Review 8 (3), 487-510.

La Porta, R., F. Lopez-de Silanes, A. Shleifer, Vishny, R., 1999. The quality of government. Journal of Law, Economics and Organization 15 (1), 222279.

La Porta, R., Shleifer, A., 2014. Informality and development. Journal of Economic Perspectives 28 (3), 109-26. 
Lassen, D.D., 2007. Ethnic divisions, trust, the size of the informal sector. Journal of Economic Behavior \& Organization 63 (3), 423-438.

Loayza, N.V., Rigolini, J., 2006. Informality trends and cycles. Policy Research Working Paper Series 4078, The World Bank.

Lomnitz, L.A., 1988. Informal exchange networks in formal systems: A theoretical model. American Anthropologist 90 (1), 42-55.

Maloney, W.F., 2004. Informality revisited. World Development 32 (7), 1159-1178.

Piketty, T., 1995. Social mobility and redistributive politics. Quarterly Journal of Economics 110, 551-584.

Pinotti, P., 2012. Trust, regulation and market failures. The Review of Economics and Statistics 94 (3), 650-658.

Portes, A., M. Castells, Benton, L., 1989. The Informal Economy: Studies in Advanced and Less Developed Countries. Baltimore: The Johns Hopkins University Press.

Portes, A., Haller, W., 2005. The informal economy. In N. Smelser and R. Swedberg (Eds.), The Handbook of Economic Sociology, Chapter 18, pp. 403-425. Princeton: Princeton University Press.

Portes, A., Sassen-Koob, S., 1987. Making it underground: Comparative material on the informal sector in western market economies. American Journal of Sociology 93 (1), 30-61.

Prado, M., 2011. Government policy in the formal and informal sectors. European Economic Review 55 (8), 1120-1136.

Putnam, R., 2000. Bowling alone: The collapse and revival of American community. New York: Simon \& Schuster.

Roeder, P. G., 2001. Ethnolinguistic fractionalization (ELF) indices, 1961 and 1985. http//:weber.ucsd.edu/proeder/elf.htm.

Schneider, F., A. Buehn, Montenegro, C., 2010. New estimates for the shadow economies all over the world. International Economic Journal 24(4), 443-461.

Schneider, F., Enste, D., 2000. Shadow economies: Size, causes, consequences. Journal of Economic Literature XXXVIII, 77-114.

Schneider, F., Enste, D.H., 2013. The Shadow Economy: An International Survey (2 ed.). Cambridge: Cambridge University Press.

Schneider, F., Williams, C.C., 2013. The Shadow Economy. London: Institute of Economic Affairs. 
Stigler, G. J., 1971. The theory of economic regulation. Bell Journal of Economics and Management Science 2, 3-21.

Straub, S., 2005. Informal sector: The credit market channel. Journal of Development Economics 78 (2), 299-321.

Tabellini, G., 2008. Presidential address. institutions and culture. Journal of the European Economic Association 6 (2-3), 255-294.

Tabellini, G., 2010. Culture and institutions: Economic development in the regions of Europe. Journal of the European Economic Association 8 (4), 677-716.

Tanzi, V., 1999. Uses and abuses of estimates of the underground economy. Economic Journal 109 (456), 338-40.

Teobaldelli, D., Schneider, F., 2013. The influence of direct democracy on the shadow economy. Public Choice 157, 543-567.

Torgler, B., Schneider, F., 2009. The impact of tax morale and institutional quality on the shadow economy. Journal of Economic Psychology 30 (2), 228-245.

Trigilia, C., 2001. Social capital and local development. European Journal of Social Theory 4 (4), 427-442.

Williams, C., 2015. Out of the shadow: Classifying economies by the extent and nature of employment in the informal economy. International Labour Review 154 (3), 331-351.

Williams, C., I. Horodnic, Windebank, J., 2015. Explaining participation in the informal economy: an institutional incongruence perspective. International sociology 30 (3), 294-313.

Williams, C.C., 2014. Out of the shadows: a classification of economies by the size and character of their informal sector. Work, Employment \& Society 28 (5),735-753.

Williams, C. C., 2017. Tackling employment in the informal economy: A critical evaluation of the neoliberal policy approach. Economic and Industrial Democracy 38 (1), 145-169.

Woolcock, M., 1998. Social capital and economic development: Toward a theoretical synthesis and policy framework. Theory and Society 27 (2), 151-208.

Yuki, K., 2007. Urbanization, informal sector, development. Journal of Development Economics 84 (1), 76-103. 